\title{
The 2006 HMDA Data
}

Robert B. Avery, Kenneth P. Brevoort, and Glenn B. Canner, of the Board's Division of Research and Statistics, prepared this article. Rebecca Tsang and Sean M. Wallace provided research assistance.

Since 1975, the Home Mortgage Disclosure Act (HMDA) has required public disclosures from most mortgage lending institutions with offices in metropolitan areas. The release of the information, which includes the geographic location and other characteristics of the home mortgages lenders originate or purchase during a calendar year, is intended to help the public determine whether institutions are adequately serving their communities' housing finance needs; the disclosures are also intended to facilitate enforcement of the nation's fair lending laws and guide investment in both the public and private sectors. Under the 1975 act, the Federal Reserve Board implements the provisions of HMDA through regulation. The Federal Financial Institutions Examination Council (FFIEC) is responsible for facilitating public access to the HMDA data and for aggregating the data by metropolitan statistical area. ${ }^{1}$

For a given calendar year, lenders covered by HMDA publicly release their loan data beginning on March 31 of the subsequent year; in the following September, the FFIEC releases summary tables pertaining to each lender and lending activity in each metropolitan statistical area, along with a file consoli-

Note: The authors express their appreciation for the late Edward M. Gramlich, member of the Federal Reserve Board from November 1997 to August 2005. His vision and persistence in seeking what became the 2002 amendments to the Board's HMDA regulations yielded the loan pricing information that has so enriched the value of the HMDA data.

1. The FFIEC (ffiec.gov) was established by federal law in 1979 as an interagency body to prescribe uniform examination procedures, and to promote uniform supervision, among the federal agencies responsible for the examination and supervision of financial institutions. The member agencies are the Board of Governors of the Federal Reserve System, the Federal Deposit Insurance Corporation, the National Credit Union Administration, the Office of the Comptroller of the Currency, and the Office of Thrift Supervision. In 1980, federal law gave the FFIEC responsibility for public access to HMDA data and for the aggregation of annual HMDA data, by census tract, for each metropolitan statistical area. In accordance with the 1980 law, the FFIEC established an advisory State Liaison Committee (SLC), composed of representatives from the Conference of State Bank Supervisors, the American Council of State Savings Supervisors, and the National Association of State Credit Union Supervisors. In 2006, the SLC joined the FFIEC as a voting member. dating virtually all the reported information. ${ }^{2}$ The nearly 8,900 lenders currently covered by the law account for an estimated 80 percent of all home lending nationwide. Because of its expansive coverage, the HMDA data likely provide a broadly representative picture of home lending in the United States.

After briefly summarizing previously published assessments of the 2004 and 2005 HMDA data and reviewing some prominent issues surrounding pricing in the mortgage market, this article analyzes the 2006 data. ${ }^{3}$ As in the analyses of the previous two years, this review focuses primarily on the pricing information included in the HMDA data and differences observed across lending institutions, geographic areas, and population groups. The article concludes with an assessment of factors that account for the variation in rates of serious delinquency on mortgage loans across counties as of March 31,2007, including information drawn from the HMDA data on the incidence of higher-priced lending and from a data file of credit scores by geographic area.

Increases in market interest rates over the course of 2004 and 2005 were an important contributor to the substantial increase between those years in the reported incidence of higher-priced lending as measured by the HMDA data. For 2006, the relatively subdued increases in market interest rates contributed to a moderation in the growth of higher-priced lending for 2006. The current disturbances in the subprime sector of the mortgage market emerged primarily in the later portions of 2006. The effects of those disturbances and of the associated changes in the regulatory environment will be reflected primarily in the HMDA data for 2007 and subsequent years.

At the outset, HMDA disclosures were limited to summary totals covering loan extensions by type of

2. Between March and September, the FFIEC member agencies systematically check the data for errors or omissions. To protect the identity of borrowers, the public data exclude the dates of loan applications and the dates of credit decisions.

3. The previously published assessments are Robert B. Avery, Glenn B. Canner, and Robert E. Cook (2005), "New Information Reported under HMDA and Its Application in Fair Lending Enforcement," Federal Reserve Bulletin, vol. 91 (Summer), pp. 344-94; and Robert B. Avery, Kenneth P. Brevoort, and Glenn B. Canner (2006), "Higher-Priced Home Lending and the 2005 HMDA Data," Federal Reserve Bulletin, vol. 92 (September 8), pp. A123-66. 
loan for each census tract but included no information on loan pricing or applications for loans that were denied by the lender. Over the years, the Congress has extended the reach of the law to a broader range of institutions and expanded the types of information that must be reported and disclosed. The most sweeping of the legislative amendments to HMDA, adopted in 1989, required disclosure of the disposition of applications for home loans and the income, sex, and race or ethnicity of the individuals applying for those loans.

Analyses of the new information revealed wide disparities in the rates of approval of loan applications across racial and ethnic lines and prompted widespread public discussion about the fairness of mortgage lending decisions. ${ }^{4}$ With the 1989 amendments, the HMDA data thus formed a new basis for public scrutiny of the fairness of mortgage lending and became an important aspect of fair lending enforcement.

In response to significant changes in the mortgage market during the 1990s, particularly the emergence and growth of subprime lending, the Federal Reserve Board in 2002 revised its Regulation C, which implements HMDA (for details, refer to the appendix). ${ }^{5}$ The revision substantially increased the type and amount of public information available about home lending in HMDA reports, beginning with data for 2004. The most important change was the requirement that lenders identify and disclose information about mortgages with annual percentage rates (APRs, which encompass interest rates and fees) above designated thresholds, mortgages referred to here as "higher-priced loans." 6 Other new disclosures included lien status of the loan (whether it is a first lien, a junior lien, or unsecured-if the latter, it is a home improvement loan), whether it is secured by a manufactured home, and whether it is subject to the protections of the Home Ownership and Equity Protection Act of 1994.

4. For example, John Goering and Ron Wienk, eds. (1996), Mortgage Lending, Racial Discrimination, and Federal Policy (Washington: Urban Institute Press).

5. Home Mortgage Disclosure Act (12 U.S.C. $§ \S 2801-11)$, Regulation C (12 C.F.R. pt. 203), and the staff commentary accompanying Regulation C (12 C.F.R. pt. 203, Supp. I).

6 . For loans with spreads above designated thresholds, revised Regulation $\mathrm{C}$ requires the reporting of the spread between the APR on a loan and the rate on Treasury securities of comparable maturity. The thresholds for reporting differ by lien status: 3 percentage points for first liens and 5 percentage points for junior, or subordinate, liens. Further details are in note 12, p. A126, of Avery, Brevoort, and Canner, "Higher-Priced Home Lending and the 2005 HMDA Data."

\section{HIGHLIGHTS OF THE 2004 AND 2005 DATA}

For both the 2004 and 2005 HMDA data, nearly 80 percent of the reporting institutions were depositories (commercial banks, savings associations, and credit unions); accounting for the rest were independent mortgage companies and mortgage companies affiliated with banking institutions or their holding companies. Although mortgage companies represented only 22 percent of the reporting institutions, they submitted information on more than 60 percent of all the reported loans and applications.

Most lenders reported relatively little home lending. The most active lenders (those providing information on at least 5,000 loans or applications) accounted for about 5 percent of the reporting institutions and nearly 90 percent of all the reported loans and applications.

A comparison of the HMDA data for 2004 and 2005 with those from earlier years documented a number of trends, including a growing share of lending to non-owner occupants, the growth of "piggyback" lending (homebuyers simultaneously obtaining two loans-one a first lien and the other a junior lien-to finance the purchase of a home), and a substantial decline in home lending insured by the Federal Housing Administration (FHA) as a share of all home lending.

Because of its importance, the new information on loan pricing was the focus of much of the analyses of the 2004 and 2005 data. The reviews found that the incidence of higher-priced lending increased from about 16 percent of all loans in 2004 to 26 percent in 2005. The substantial narrowing of the difference between short- and long-term interest rates in 2005 explained part of the increase that year in the share of reported loans that exceeded the pricing thresholds established by Regulation C. ${ }^{7}$ Estimates suggested that the changes in interest rates accounted for about 15 percent of the increase in reported higher-priced lending for conventional fixed-rate home-purchase loans and about 20 percent of the increase for similar

7. Additional research on the possible reasons for the increase in reported higher-priced lending from 2004 to 2005 is in Michael LaCour-Little (2007), "Economic Factors Affecting Home Mortgage Disclosure Act Reporting," paper prepared for the American Real Estate and Urban Economics Association Mid-Year Meeting, Washington, May 29-30. The study finds that, after controlling for the mix of loan types, for credit-risk factors, and for changes in the relationship between short- and long-term interest rates, there was no statistically significant increase in the volume of higher-priced lending for loans originated directly by lenders, but there was an increase for such loans originated through indirect channels. 
loans for refinancings. Another portion of the increase in higher-priced lending was attributable to the effects of the narrowing spread between short- and long-term interest rates on adjustable-rate lending, but available data limited the ability to quantify this effect. Besides changes in market interest rates, other factorschanges in borrower credit-risk profiles and changes in lender business practices such as an increased willingness to accept higher-risk borrowers - may also have led to increased higher-priced lending from 2004 to 2005; but again, quantifying the influences was impeded by data limitations.

Analysis of the 2004 and 2005 pricing information also found that the incidence of higher-priced lending varied substantially by geography and loan characteristic and across borrower groups. The incidence was found to be elevated for borrowers residing in census tracts characterized by larger proportions of individuals with lower credit scores and lower high-school graduation rates; and in census tracts with larger proportions of lower-income households, minority households, and shares of loan applicants that were denied credit. ${ }^{8}$ The incidence of higher-priced lending was also elevated for smaller loans and piggyback loans, for loans made by depository institutions outside their local communities, and for loans originated by independent mortgage companies regardless of location.

Results of an analysis along racial and ethnic lines were consistent with the results by geography: Blacks and Hispanic whites were more likely, and Asians somewhat less likely, to have received higher-priced loans than non-Hispanic whites. Information included in the HMDA data on characteristics of borrowers and loans-such as income, amount borrowed, and property location-does not account fully for the variation in loan pricing across geographies and groups. However, many factors routinely used by lenders to underwrite and price loans-including loan-to-value (LTV) ratios and measures of borrower credit history (for example, a credit history score)are not included in the HMDA data and, consequently, cannot be included in an analysis of pricing differences that relies on the HMDA data alone.

The expanded HMDA data have both raised concerns about the fairness of the lending process and created new avenues for lenders, regulators, and the public to address fairness. Lenders are responsible for their compliance with fair lending laws, and the HMDA data can both encourage and facilitate the improvement of their compliance efforts. Likewise,

8. The term "minority" as used in this article refers to any racial or ethnic identity other than non-Hispanic white. the regulatory agencies have been using the expanded data in their fair lending enforcement activities. The expanded data also increase transparency in the marketplace by identifying lenders active in the higherpriced segment of the market and by allowing a wide variety of analyses that more fully describe higherpriced lending.

\section{LOAN PRICING IN THE MoRTGAGE MARKET}

Mortgage markets have changed greatly over the years. Historically, mortgage lenders offered consumers a relatively limited array of loan products. The prices (interest rates, points, and fees) at which they offered their loans varied mainly by

- loan type-for example, conventional or government-backed

- loan type characteristic-including amount borrowed, term to maturity, and LTV ratio

- loan/type of structure securing the loan-traditional "site built" home, factory-manufactured unit, or multifamily units

- ownership status-owner occupied or non-owner occupied

The prices did not, however, vary to any great degree by the creditworthiness of the borrower; effectively, borrowers either did or did not meet the underwriting criteria for a particular loan product, and the borrowers who met the criteria all paid about the same price.

In the past quarter century, advances in technology, improvements in access to the credit histories of individuals, and the emergence of a robust secondary market for loans over the full spectrum of credit risks have helped spur remarkable changes in the mortgage market. The most prominent of those developments has been the explicit risk-based pricing of credit. Over this period, more so than in the past, differences in the creditworthiness of different borrowers led to different prices for the same product. ${ }^{9}$ Lesscreditworthy applicants, or those either unwilling or unable to document their creditworthiness or income, found it increasingly likely that they would be granted a loan but that it would be offered at a price higher than that for more-creditworthy applicants.

Explicit risk-based pricing has expanded opportunities for homeownership and allowed individuals, including those who otherwise have little access to credit, to more readily purchase homes or borrow

9. Refer, for example, to Souphala Chomsisengphet and Anthony Pennington-Cross (2006), "The Evolution of the Subprime Mortgage Market," Federal Reserve Bank of St. Louis, Review, vol. 88 (January/ February), pp. 31-56. 
against the equity they have accumulated in their homes. Recent developments in mortgage markets have caused some lenders to tighten underwriting and charge higher prices to compensate for perceived risk. However, risk-based pricing continues to be a feature of the mortgage market. Although risk-based pricing has broadened opportunities for many consumers, it has been accompanied by growing concerns, some of which are noted below.

\section{Segments of the Market}

Broadly, borrowers in the higher-priced mortgage market generally fall into one of two "nonprime" market segments: "subprime" and "near prime." Individuals in the subprime category pay the highest prices because they are considered to pose the greatest risk of default or prepayment. ${ }^{10}$ Such borrowers may also impose higher costs of origination, as it can be more difficult and time consuming to assess their credit profiles. Borrowers in the prime market pay the lowest prices for loans, subprime borrowers pay the highest prices, and near-prime borrowers pay prices somewhere in between. In practice, the dividing line between subprime and near prime is amorphous, as is the line between the prime and nonprime markets. The distinctions between all these market segments change over time as market interest rates move, as lenders' appetite for interest rate risk and the risks of prepayment and default changes, and as the ability to price risk more exactly changes.

Industry sources provide some data on the relative sizes of these market segments. For example, in 2006 about 20 percent of mortgages were subprime, and about 13 percent were near prime (often referred to as "alt-A" mortgages). ${ }^{11}$

\section{Nontraditional Loan Products}

Over the first half of this decade, home values in many areas of the country rose sharply, as did the competitive pressures on lenders to innovate. Those forces encouraged lenders to develop loan products that were intended to hold down required monthly payments, at least for the first few years of the loan. Among those products were interest-only loans, adjustable-rate loans with discounted (“teaser") initial rates, and payment option loans, which increased the

10. Prepayment penalties are a common feature of loans in the subprime market and are intended to address the elevated risk of prepayment.

11. Inside Mortgage Finance (2007), The 2007 Mortgage Market Statistical Annual, vol. 1: The Primary Market (Bethesda, Md.: Inside Mortgage Finance Publications). affordability of home purchases and mortgage refinancings, at least in the short term. However, these loan products sometimes are accompanied by minimal down payments (or a piggyback loan), and the limited or zero repayment of principal in the amortization schedule of many of these loan products means that mortgage payments generate little or no additional equity in the first few years. These loans also generally involve an increase in monthly payments at some point later in the life of the loan. Recent evidence indicates, however, that these so-called nontraditional loan products have elevated incidence of default and foreclosure, particularly when extended in combination with other indicators of elevated credit risk, such as a low credit score or no documentation of income. Such loan products have also drawn considerable attention from regulatory authorities, which have provided guidance to banking institutions on the risks posed by those products and the importance of providing clear disclosure of the loan terms and conditions. ${ }^{12}$

\section{The Role of Brokers}

Another notable development in the mortgage market was the emergence of brokers as the intermediary through which the majority of individuals obtain a mortgage. ${ }^{13}$ Historically, prospective borrowers visited an office of a local banking institution to apply for a loan. Today, a mortgage broker, often working as an independent entity, may take loan applications on behalf of a banking institution or other mortgage lender and may provide the only direct contact with the borrower until closing, when the loan documents are signed and the mortgage is issued. In such cases, the mortgage broker plays an important role in pricing the loan, and frequently the compensation received by the broker is based, in whole or in part, on the interest rate and fees paid by the consumer.

The large role played by brokers in the lending process gained increased attention in the past year or so as delinquencies, defaults, and foreclosures increased, particularly in the subprime portion of the mortgage market. Among the issues that have drawn

12. For example, on September 29, 2006, the federal financial regulatory agencies (Board of Governors of the Federal Reserve System, Federal Deposit Insurance Corporation, National Credit Union Administration, Office of the Comptroller of the Currency, and Office of Thrift Supervision) issued the press release "Interagency Guidance on Nontraditional Mortgage Product Risks," www.federalreserve.gov/ boarddocs/press/bcreg/2006/20060929/default.htm.

13. Industry sources indicate that mortgage brokers initiated 58 percent of the mortgage originations in 2006, down somewhat from 63 percent in 2005 (Lew Sichelman, 2007, "Broker Market Share Down to 58\%," National Mortgage News, July 9, p. 1). 
increased scrutiny to brokers are whether they provide consumers with sufficient information to make sound choices in selecting a mortgage product and whether fraud has sometimes been involved in the broker's characterization of the borrower's creditworthiness or in the appraisal of the home being purchased. Also, brokers and, many times, the lenders originating the loan do not bear the credit risk of the loans they sell but share in the profits from originating the loan. As a result, the broker or other originating party may not have the incentive to fully pass along to the loan purchasers all relevant information needed to gauge the accuracy and completeness of the information used to underwrite and price the loan. ${ }^{14}$

\section{Concerns about Loan Pricing}

As price flexibility has emerged in the mortgage market, so have concerns about the fairness of pricing outcomes. Such concerns generally fall into four broad categories. First are concerns about possible discrimination based on the race or ethnicity of the borrower. Such concerns are heightened because loan prices are not always determined strictly on the basis of credit risk or cost factors but can involve elements of discretion by loan officers or loan brokers, such as seeking prices that differ from the lender's baseline price guidance typically conveyed in the form of rate sheets.

Second are concerns about whether borrowers in the higher-priced segment of the loan market are sufficiently informed and whether they are willing or able to shop effectively for the loan terms most appropriate to their circumstances. For example, it may be difficult for borrowers to determine where they fit along the credit-risk spectrum. Also, some borrowers may fail to shop or negotiate for the best available rates and terms because they need funds immediately; such borrowers tend to focus primarily on the amount they can borrow and the size of the monthly payment. Such borrowers may not fully appreciate the potential longer-run consequences of certain loan terms such as prepayment penalties, adjustable interest rates, negative amortization, and balloon payments. Such borrowers may be more easily exploited by loan officers or brokers. Also, aggressive marketing tactics may confuse such borrowers about the cost and terms of loans.

14. In some cases, brokers and loan originators are subject to forced repurchase of a loan that was sold if it performs poorly soon after loan origination or if representations and warranties were violated; but in practice, brokers and some of the firms they sometimes work with have limited capacity to fund a repurchase.
Third, concerns have been raised about whether competition is adequate to ensure that borrowers in the higher-priced segment of the loan market have access to the full range of credit opportunities. Some believe that prime-market lenders are not present or do not offer or promote their prime products sufficiently in certain geographic markets, including neighborhoods that have larger minority populations. In this view, reduced access to prime lenders and their products limits the opportunities for borrowers in affected communities to access lower-priced loans.

Finally, the elevated default and foreclosure rates currently experienced in the higher-priced portion of the loan market have raised concerns about the sustainability of homeownership, the adverse effects on neighborhoods with higher concentrations of these loans, and the hardship on borrowers who are losing their homes. Recognizing these concerns, the federal and state financial institution regulatory agencies have encouraged lenders and servicers of loans to work with mortgage borrowers facing financial difficulties. ${ }^{15}$

These various concerns about the functioning of the mortgage market raise important public policy issues that are beyond the scope of this article. Nonetheless, the expanded HMDA data provide information that has proven useful in understanding and addressing many of these issues.

\section{GENERAL FINDINGS FROM THE 2006 HMDA DATA}

For 2006, lenders covered by HMDA reported information on 27.5 million applications for home loans. Almost all the applications were for loans to be secured by one- to four-family (so-called singlefamily) houses, as follows: 10.9 million applications to purchase a home, 2.5 million to make home improvements, and 14.0 million to refinance an existing home loan. The balance (about 0.1 million) was for loans secured by multifamily dwellings-those

15. On April 17, 2007, the federal financial regulatory agencies issued guidance to encourage supervised institutions to work constructively with homeowners who are financially unable to continue meeting their mortgage payments (www.federalreserve.gov/boarddocs/ srletters/2007/SR0706). On September 4, 2007, the federal financial regulatory agencies and the Conference of State Bank Supervisors (CSBS) issued a statement encouraging federally regulated financial institutions and state-supervised entities that service securitized residential mortgages to determine the full extent of their authority under pooling and servicing agreements to identify borrowers at risk of default and pursue appropriate loss mitigation strategies designed to preserve homeownership ("Federal Financial Regulatory Agencies and CSBS Issue Statement on Loss Mitigation Strategies for Servicers of Residential Mortgages," www.federalreserve.gov/newsevents/press/ bcreg/20070904a.htm). 
1. Home loan and reporting activity of home lenders covered under HMDA, 1990-2006

Number

\begin{tabular}{|c|c|c|c|c|c|c|c|c|}
\hline \multirow{3}{*}{ Year } & \multicolumn{6}{|c|}{$\begin{array}{l}\text { Applications received for home loans on one- to four-family properties, } \\
\text { and home loans purchased from other lenders (millions) }\end{array}$} & \multirow{3}{*}{ Reporters } & \multirow{3}{*}{$\begin{array}{l}\text { Disclosure } \\
\text { reports }^{2}\end{array}$} \\
\hline & \multicolumn{4}{|c|}{ Applications } & \multirow{2}{*}{$\begin{array}{l}\text { Loans } \\
\text { purchased }\end{array}$} & \multirow[b]{2}{*}{ Total $^{1}$} & & \\
\hline & $\begin{array}{l}\text { Home } \\
\text { purchase }\end{array}$ & Refinance & $\begin{array}{c}\text { Home } \\
\text { improvement }\end{array}$ & Total $^{1}$ & & & & \\
\hline 1990 . & 3.3 & 1.1 & 1.2 & 5.5 & 1.2 & 6.7 & 9,332 & 24,041 \\
\hline 1991. & 3.3 & 2.1 & 1.2 & 6.6 & 1.4 & 7.9 & 9,358 & 25,934 \\
\hline 1992 & 3.5 & 5.2 & 1.2 & 10.0 & 2.0 & 12.0 & 9,073 & 28,782 \\
\hline 1993. & 4.5 & 7.7 & 1.4 & 13.6 & 1.8 & 15.4 & 9,650 & 35,976 \\
\hline 1994. & 5.2 & 3.8 & 1.7 & 10.7 & 1.5 & 12.2 & 9,858 & 38,750 \\
\hline 1995 & 5.5 & 2.7 & 1.8 & 10.0 & 1.3 & 11.2 & 9,539 & 36,611 \\
\hline 1996 . & 6.3 & 4.5 & 2.1 & 13.0 & 1.8 & 14.8 & 9,328 & 42,946 \\
\hline 1997. & 6.8 & 5.4 & 2.2 & 14.3 & 2.1 & 16.4 & 7,925 & 47,416 \\
\hline 1998. & 8.0 & 11.4 & 2.0 & 21.4 & 3.2 & 24.7 & 7,836 & 57,294 \\
\hline 1999 & 8.4 & 9.4 & 2.1 & 19.9 & 3.0 & 22.9 & 7,832 & 56,966 \\
\hline $2000 \ldots \ldots$ & 8.3 & 6.5 & 2.0 & 16.8 & 2.4 & 19.2 & 7,713 & 52,776 \\
\hline $2001 \ldots$ & 7.7 & 14.3 & 1.9 & 23.8 & 3.8 & 27.6 & 7,631 & 53,066 \\
\hline 2002 . & 7.4 & 17.5 & 1.5 & 26.4 & 4.8 & 31.2 & 7,771 & 56,506 \\
\hline $2003 \ldots$ & 8.2 & 24.6 & 1.5 & 34.3 & 7.2 & 41.5 & 8,121 & 65,808 \\
\hline $2004 \ldots$ & 9.8 & 16.1 & 2.2 & 28.1 & 5.1 & 33.3 & 8,853 & 72,246 \\
\hline $2005 \ldots \ldots$ & 11.7 & 15.9 & 2.5 & 30.2 & 5.9 & 36.0 & 8,848 & 78,193 \\
\hline $2006 \ldots \ldots$ & 10.9 & 14.0 & 2.5 & 27.5 & 6.2 & 33.7 & 8,886 & 78,638 \\
\hline
\end{tabular}

Note: Here and in subsequent tables except table 3, applications exclude requests for pre-approval that were denied by the lender or were accepted by the lender but not acted upon by the borrower. In this article, applications are defined as being for a loan on a specific property; they are thus distinct from requests for pre-approval, which are not related to a specific property.

1. Applications for multifamily homes are included only in the total columns; for 2006, these applications numbered nearly 52,380.

for five or more families (table 1). These applications resulted in nearly 14 million loan extensions. Lenders also reported information on 6.2 million loans they had purchased from other institutions and on 411,000 requests for pre-approvals of home-purchase loans; the pre-approval requests either were turned down by the lender or (not shown in table) were granted but not acted on by the applicant.

The total number of reported applications and purchased loans fell 2.3 million, or 6 percent, from 2005; most of the decline was for refinancings. The number of applications for loans to refinance an existing loan fell 1.9 million, or about 12 percent; the number declined most likely because short-term interest rates increased from the end of 2005 through much of 2006 and thereby reduced the number of existing loans that could be refinanced at a lower rate. Slower house-price appreciation and, in some areas, outright declines in property values also likely diminished the attractiveness of refinancing or the borrower's ability to refinance.

For 2006, HMDA reporting requirements covered 8,886 institutions-including 3,900 commercial banks, 946 savings institutions, 2,036 credit unions, and 2,004 mortgage companies (table 2). Of the mortgage companies, two-thirds were independent entities - that is, they were neither subsidiaries of
2. A report covers the mortgage lending activity of a lender in a single metropolitan statistical area in which it had an office during the year.

Source: Here and in subsequent tables and figures except as noted, Federal Financial Institutions Examination Council, data reported under the Home Mortgage Disclosure Act (www.ffiec.gov/hmda).

depository institutions nor affiliates of bank holding companies (data derived from table). The total number of reporting institutions was about the same as that in 2005 , as was the distribution of reporters by type of institution.

\section{Activity and Size of Lender}

As in earlier years, most of the institutions reporting HMDA data are small whether measured by asset size or by some indicator of lending activity such as the number of reported applications or loans (table 3). For 2006, 60 percent of the reporting institutions,

2. Distribution of home lenders covered by HMDA, by type of institution, 2006

\begin{tabular}{|c|c|c|}
\hline Type & Number & Percen \\
\hline Depository institution & & \\
\hline Commercial bank .... & 3,900 & 43.9 \\
\hline Savings institution . & 946 & 10.6 \\
\hline Credit union $\ldots . .$. & 2,036 & 22.9 \\
\hline All ........ & 6,882 & 77.4 \\
\hline $\begin{array}{l}\text { Mortgage company } \\
\text { Independent ....... }\end{array}$ & 1,328 & 14.9 \\
\hline Affiliated $^{1} \ldots \ldots \ldots$ & 676 & 7.6 \\
\hline All ..... & 2,004 & 22.5 \\
\hline All institutions .............. & 8,886 & 100 \\
\hline
\end{tabular}

1. Subsidiary of a depository institution or an affiliate of a bank holding company. 
each of which provided information on fewer than 250 loans or applications, accounted for just 1.7 percent of all the reported data. At the other extreme, 5 percent of reporting institutions, each of which provided information on 5,000 or more loans or applications, accounted for 87 percent of all the reported data.

Many HMDA reporters are affiliated with each other. If individual HMDA reporters are aggregated to their highest level of corporate organization (such as a holding company), the concentration of mortgage lending nationwide is evident. The twenty-five organizations reporting the largest number of applications and loans accounted for 54 percent of the 2006 data, roughly the same proportions as in the 2004 and 2005 HMDA data (data not shown in tables).

\section{Disposition of Applications, Loan Types, and HOEPA-Related Activities}

For purposes of analysis, loan applications and loans can be grouped in many ways; here the analysis focuses on twenty-five distinct product categories characterized by loan and property type, purpose of the loan, and lien and owner-occupancy status. Each product category contains information on the number of total and pre-approval applications, application denials, originated loans, loans with prices above the thresholds, loans covered by the Home Ownership and Equity Protection Act of 1994 (HOEPA), and the mean and median APR spreads for loans priced above the designated reporting thresholds (tables 4 and 5). ${ }^{16}$

\section{Disposition of Applications}

HMDA data are the only publicly available source of information on the disposition of individual applications for home loans. The data include information on the race, ethnicity, and sex of applicants as well as the type and purpose of the loan and the location of the property, so the disposition of applications can be assessed along many dimensions.

The HMDA data for 2006, like those from earlier years, indicate that lenders approve most of the applications they receive, although the proportion approved or denied varies by loan purpose, type of loan and property, and lien status. In general, denial

16. Transition rules governing the reporting of the expanded HMDA data created problems for assessing the data on loan pricing, manufactured-home lending, and pre-approvals. The transition rules had a large influence on the data reported for 2004 and a much smaller effect on the 2005 data. In the 2006 data, transition rules affected only about 6,000 applications and 1,100 loans; the presentation here excludes those applications and loans for analyses that pertain to pricing, manufactured-home lending, and pre-approvals. rates are higher for refinancings and for homeimprovement loans than for home-purchase loans, perhaps because of the prequalification and financial counseling activities that many prospective borrowers go through before purchasing a home (table 4). Denial rates are lower for government-backed loans than for conventional loans but are especially high for loans to purchase manufactured homes. Overall, the denial rate for all home loans in 2006 was 29 percent, compared with 27 percent in 2005.

\section{Conventional and Government-Backed Loans}

Consistent with earlier years, most reported home loan activity in 2006 involved conventional loansthat is, non-government-backed loans (table 4). Such loans accounted for about 95 percent of all loans originated in 2006. FHA-insured loans accounted for about three-fourths of the government-backed loans, and most of the rest involved guarantees by the Department of Veterans Affairs (VA) (data not shown in tables). The share of all HMDA-reported loans backed by the FHA has fallen over the past several years, from about 16 percent in 2000 to less than 3 percent in 2005 and 2006 (data not shown in tables). ${ }^{17}$ (The FHA share of first-lien home-purchase loans has also been trending down and in 2006 was about 5 percent.) The development in recent years of many conventional loan products that feature moreflexible and quicker underwriting has attracted borrowers who, in the past, might have sought loans with FHA backing. Among the newer conventional loan products are those intended to serve borrowers who are seeking to minimize their down payment or initial monthly payments or who are unable or unwilling to document their incomes. Also, in some areas of the country, high home prices have diminished the attractiveness of the FHA program, as increases in the maximum loan value that the FHA will insure have failed to keep pace with increases in local home values.

For each loan made, the HMDA data show the amount borrowed and the incomes of the borrowers. The analysis that follows immediately in this section considers four loan categories: (1) conventional loans that met the definition of higher-priced loans under HMDA, (2) all other conventional loans, (3) FHAinsured loans, and (4) VA-guaranteed loans. The analysis is limited to site-built, owner-occupied, one-

17. VA-backed lending has also fallen some in recent years as a share of the overall market, but not to the same extent as FHA-backed lending. For example, VA-guaranteed loans accounted for 3.5 percent of home purchase loans in 2000 and about 2 percent in 2006. 
3. Distribution of home lenders covered by HMDA, by type of lender and the number of applications they receive, 2006

\begin{tabular}{|c|c|c|c|c|c|c|}
\hline \multirow{2}{*}{$\begin{array}{l}\text { Type of lender, and } \\
\text { subcategory (asset size } \\
\text { in millions of dollars, } \\
\text { or affiliation) }\end{array}$} & \multicolumn{2}{|c|}{$1-99$} & \multicolumn{2}{|c|}{$100-249$} & \multicolumn{2}{|c|}{$250-999$} \\
\hline & $\begin{array}{l}\text { Percent of } \\
\text { lender type }\end{array}$ & $\begin{array}{l}\text { Percent of } \\
\text { subcategory }\end{array}$ & $\begin{array}{l}\text { Percent of } \\
\text { lender type }\end{array}$ & $\begin{array}{l}\text { Percent of } \\
\text { subcategory }\end{array}$ & $\begin{array}{l}\text { Percent of } \\
\text { lender type }\end{array}$ & $\begin{array}{c}\text { Percent of } \\
\text { subcategory }\end{array}$ \\
\hline \multicolumn{7}{|l|}{ Depository institution } \\
\hline Less than 250 & 75.8 & 60.5 & 63.1 & 28.7 & 25.4 & 9.9 \\
\hline $250-999 \ldots \ldots$ & 19.2 & 26.9 & 32.0 & 25.4 & 60.5 & 41.3 \\
\hline 1,000 or more & 5.0 & 17.7 & 5.0 & 10.0 & 14.1 & 24.2 \\
\hline All .......... & 100 & 44.4 & 100 & 25.3 & 100 & 21.7 \\
\hline \multicolumn{7}{|l|}{ Savings institution } \\
\hline Less than 250 .. & 84.4 & 46.9 & 64.3 & 34.9 & 22.5 & 16.2 \\
\hline $250-999 \ldots \ldots$ & 12.7 & 8.7 & 33.6 & 22.4 & 66.5 & 58.8 \\
\hline 1,000 or more & 2.9 & 4.7 & 2.1 & 3.3 & 11.1 & 23.3 \\
\hline All .......... & 100 & 25.8 & 100 & 25.2 & 100 & 33.4 \\
\hline \multicolumn{7}{|l|}{ Credit union } \\
\hline Less than 250 & 96.0 & 62.8 & 82.3 & 26.8 & 34.9 & 10.3 \\
\hline $250-999 \ldots \ldots$ & 3.8 & 8.4 & 16.8 & 18.4 & 57.9 & 57.1 \\
\hline 1,000 or more & .2 & 1.7 & .8 & 3.5 & 7.1 & 27.0 \\
\hline All ......... & 100 & 47.6 & $100^{\circ}$ & 23.6 & 100 & 21.4 \\
\hline \multicolumn{7}{|l|}{ All depository institutions } \\
\hline Less than $250 \ldots \ldots \ldots$ & 83.1 & 59.9 & 68.7 & 28.6 & 27.4 & 10.7 \\
\hline $250-999 \ldots \ldots$ & 13.6 & 19.7 & 27.9 & 23.4 & 61.0 & 47.8 \\
\hline 1,000 or more . & 3.3 & 12.7 & 3.4 & 7.7 & 11.6 & 24.4 \\
\hline All .......... & 100 & 42.8 & 100 & 24.8 & 100 & 23.2 \\
\hline \multicolumn{7}{|l|}{ Mortgage company } \\
\hline Independent .... & 37.7 & 12.1 & 63.6 & 13.2 & 77.0 & 30.2 \\
\hline Affiliated ......... & 62.3 & 39.1 & 36.4 & 14.8 & 23.0 & 17.8 \\
\hline All ... & 100 & 21.2 & 100 & 13.7 & 100 & 26.0 \\
\hline All institutions $\ldots \ldots \ldots$ & $\ldots$ & 37.9 & $\ldots$ & 22.3 & $\ldots$ & 23.8 \\
\hline \multirow{3}{*}{\multicolumn{7}{|c|}{$\begin{array}{l}\text { Mемо } \\
\text { Percent of all applications, } \\
\text { by number reported }\end{array}$}} \\
\hline & & & & & & \\
\hline & $\ldots$ & .5 & $\ldots$ & 1.2 & $\ldots$ & 3.8 \\
\hline
\end{tabular}

Note: Refer to table 2, note 1 . As stated in the general note to table 1, applications in the present table include requests for pre-approval that were denied by the lender or were accepted by the lender but not acted upon by the borrower.

1. Distribution sums vertically. For example, the first column, first row shows that 75.8 percent of commercial banks that received 1-99 applications in 2006 had assets of less than $\$ 250$ million.

to four-family units, and the four categories are applied separately to home-purchase loans and refinancings.

As noted, distinguishing higher-priced loans from others is one way to differentiate lending activity. A second approach is to distinguish between loans originated for a "conforming" loan amount and those that were larger (jumbo loans). ${ }^{18}$ Fannie Mae and Freddie Mac hold some of their purchased loans in their own portfolios, but they convert most of them into securities, which they sell to investors. For 2006 the size limit for conforming loans was $\$ 417,000$ for a single-family property in the continental United

18. The government-sponsored enterprises Fannie Mae and Freddie Mac are permitted to purchase only those mortgages that are in conformance with annually adjusted size limits and certain other underwriting criteria. The HMDA reports do not provide all the data needed to determine whether a loan is conforming, so a mortgage falling within the "conforming loan amount" limit may not meet the other criteria for conforming loans and thus might not be eligible for purchase by Fannie Mae and Freddie Mac.
2. Distribution sums horizontally. For example, the second column, first row shows that 60.5 percent of commercial banks with assets of less than $\$ 250$ million received 1-99 applications in 2006.

.. Not applicable.

States and 50 percent higher for such a property in Alaska and Hawaii and in Guam and the U.S. Virgin Islands. The size limits for conforming loans are higher for structures accommodating two, three, or four families. However, the HMDA data do not distinguish among properties with fewer than five units, so in this article the discussion of 2006 loans with a conforming size refers to the $\$ 417,000$ limit for single-family properties in the continental United States, a size that included most home loans extended in $2006 .{ }^{19}$

Indeed, for 2006, about 90 percent of conventional loans for purchase and likewise for refinancing, whether higher-priced or not, were within the singlefamily conforming loan-size limit (table 6). Higherpriced loans tended to be somewhat smaller than

19. The 2006 limits, which ranged up to $\$ 801,950$ for a four-family unit, are given in Fannie Mae (2005), "Fannie Mae Announces 2006 Conforming Loan Limit of \$417,000," press release, Nov. 29, www.fanniemae.com/newsreleases/2005/3649.jhtml. 
3. Distribution of home lenders covered by HMDA, by type of lender and the number of applications they receive, 2006-Continued

\begin{tabular}{|c|c|c|c|c|c|c|c|c|}
\hline \multirow{2}{*}{$\begin{array}{c}\text { Type of lender, and } \\
\text { subcategory (asset size } \\
\text { in millions of dollars, } \\
\text { or affiliation) }\end{array}$} & \multicolumn{2}{|c|}{$1,000-4,999$} & \multicolumn{2}{|c|}{5,000 or more } & \multicolumn{2}{|c|}{ Any } & \multicolumn{2}{|c|}{ Мемо } \\
\hline & $\begin{array}{l}\text { Percent of } \\
\text { lender type }\end{array}$ & $\begin{array}{c}\text { Percent of } \\
\text { subcategory }\end{array}$ & $\begin{array}{l}\text { Percent of } \\
\text { lender type }\end{array}$ & $\begin{array}{c}\text { Percent of } \\
\text { subcategory }\end{array}$ & $\begin{array}{l}\text { Percent of } \\
\text { lender type }\end{array}$ & $\begin{array}{c}\text { Percent of } \\
\text { subcategory }\end{array}$ & $\begin{array}{l}\text { Number of } \\
\text { lenders }\end{array}$ & $\begin{array}{c}\text { Percent of } \\
\text { applications }\end{array}$ \\
\hline \multicolumn{9}{|l|}{ Depository institution } \\
\hline Less than 250 & 6.3 & .7 & 5.0 & .2 & 55.6 & 100 & 2,170 & 1.1 \\
\hline $250-999 \ldots \ldots \ldots$ & 30.9 & 6.4 & .0 & .0 & 31.7 & 100 & 1,238 & 1.6 \\
\hline 1,000 or more & 62.9 & 32.7 & 95.0 & 15.5 & 12.6 & 100 & 492 & 22.0 \\
\hline All ......... & 100 & 6.6 & 100 & 2.1 & 100 & 100 & 3,900 & 24.7 \\
\hline \multicolumn{9}{|l|}{ Savings institution } \\
\hline Less than 250 & 6.4 & 1.4 & 5.6 & .7 & 46.4 & 100 & 439 & .3 \\
\hline $250-999 \ldots \ldots \ldots \ldots$ & 35.1 & 9.2 & 5.6 & .8 & 37.7 & 100 & 357 & .9 \\
\hline 1,000 or more $\ldots \ldots \ldots$ & 58.5 & 36.7 & 88.9 & 32.0 & 15.9 & 100 & 150 & 9.9 \\
\hline All $\ldots \ldots \ldots \ldots$ & 100 & 9.9 & 100 & 5.7 & 100 & 100 & 946 & 11.1 \\
\hline \multicolumn{9}{|l|}{ Credit union } \\
\hline Less than 250 & 1.5 & .1 & .0 & .0 & 72.7 & 100 & 1,480 & 6 \\
\hline $250-999 \ldots \ldots$ & 51.5 & 16.1 & .0 & .0 & 21.7 & 100 & 441 & .9 \\
\hline 1,000 or more $\ldots$ & 47.1 & 56.5 & 100 & 11.3 & 5.7 & 100 & 115 & 1.3 \\
\hline All ................. & 100 & 6.8 & 100 & .6 & 100 & 100 & 2,036 & 2.8 \\
\hline \multicolumn{9}{|l|}{ All depository institutions } \\
\hline Less than $250 \ldots \ldots \ldots$ & 4.9 & .6 & 4.8 & .2 & 59.4 & 100 & 4,089 & 2.0 \\
\hline $250-999 \ldots \ldots \ldots \ldots$ & 37.5 & 9.0 & 2.0 & .2 & 29.6 & 100 & 2,036 & 3.4 \\
\hline 1,000 or more $\ldots \ldots \ldots \ldots \ldots$ & 57.6 & 37.1 & 93.2 & 18.1 & 11.0 & 100 & 757 & 33.1 \\
\hline All $\ldots \ldots \ldots \ldots$ & 100 & 7.1 & 100 & 2.1 & 100 & 100 & 6,882 & 38.5 \\
\hline \multicolumn{9}{|l|}{ Mortgage company } \\
\hline Independent ........... & 78.7 & 28.0 & 70.7 & 16.6 & 66.3 & 100 & 1,328 & 36.7 \\
\hline Affiliated ............... & 21.4 & 14.9 & 29.3 & 13.5 & 33.7 & 100 & 676.0 & 24.7 \\
\hline All .... & 100 & 23.6 & 100 & 15.5 & 100 & 100 & 2,004 & 61.5 \\
\hline \multirow{3}{*}{$\begin{array}{l}\text { All institutions } \ldots \ldots \ldots \ldots \ldots \ldots \\
\text { Memo } \\
\text { Percent of all applications, } \\
\text { by number reported } \\
\text { by lender } . \ldots \ldots \ldots \ldots \ldots \ldots \ldots\end{array}$} & $\cdots$ & 10.8 & $\ldots$ & 5.2 & $\ldots$ & 100 & 8,886 & 100 \\
\hline & & & & & & & & \\
\hline & $\ldots$ & 7.5 & & 87.0 & & 100 & 8,886 & 100 \\
\hline
\end{tabular}

others; for example, among conventional homepurchase loans, the mean size of higher-priced mortgages was $\$ 209,000$, compared with $\$ 246,000$ for others (table 6, memo item).

By their nature, government-backed loans tend to be considerably smaller than conventional loans; the difference reflects the relatively low guarantees or insurance limits in the government-backed programs and the focus of the programs on lower- and middleincome borrowers. In 2006, for example, the mean size of FHA-insured home-purchase loans was $\$ 133,000$, and nearly half of such loans were for less than $\$ 125,000$, whereas only about one-fourth of the conventional loans were in that size range.

Borrower incomes differ substantially by loan product (table 7). Not surprisingly, the mean income of borrowers with conventional loans was substantially larger than that of borrowers with governmentbacked loans. Among those obtaining conventional home-purchase mortgages, the mean income of individuals with a loan of conforming size was $\$ 82,400$, versus a mean income of $\$ 258,000$ for those with a jumbo loan. And, again among borrowers using conventional loans, those using higher-priced loans either to purchase a home or to refinance had a mean income about 20 percent lower than borrowers not paying higher prices.

\section{Non-Owner-Occupant Lending}

Part of the strong performance of housing markets over the first half of this decade can be traced to the growth in sales of homes to investors or individuals purchasing second or vacation homes, units collectively described as "non-owner occupied." HMDA data can document the role of investors and secondhome buyers in the housing market because the data indicate whether the subject property is intended as the borrower's principal dwelling (that is, as an owner-occupied unit). ${ }^{20} \mathrm{~A}$ limitation on this type of analysis is that some buyers do not use home mortgages to finance their purchase; rather, they pay cash for the properties or, in some instances, take out commercial loans. After declining in the early 1990s,

20. An investment property is a non-owner-occupied dwelling that is intended to be continuously rented. Non-owner-occupied unitsvacation homes and second homes - that are for the primary use of the owner are not considered investment properties. The HMDA data do not, however, distinguish between these two types of non-owneroccupied dwellings. 
4. Disposition of applications for home loans, and origination and pricing of loans, by type of home and type of loan, 2006

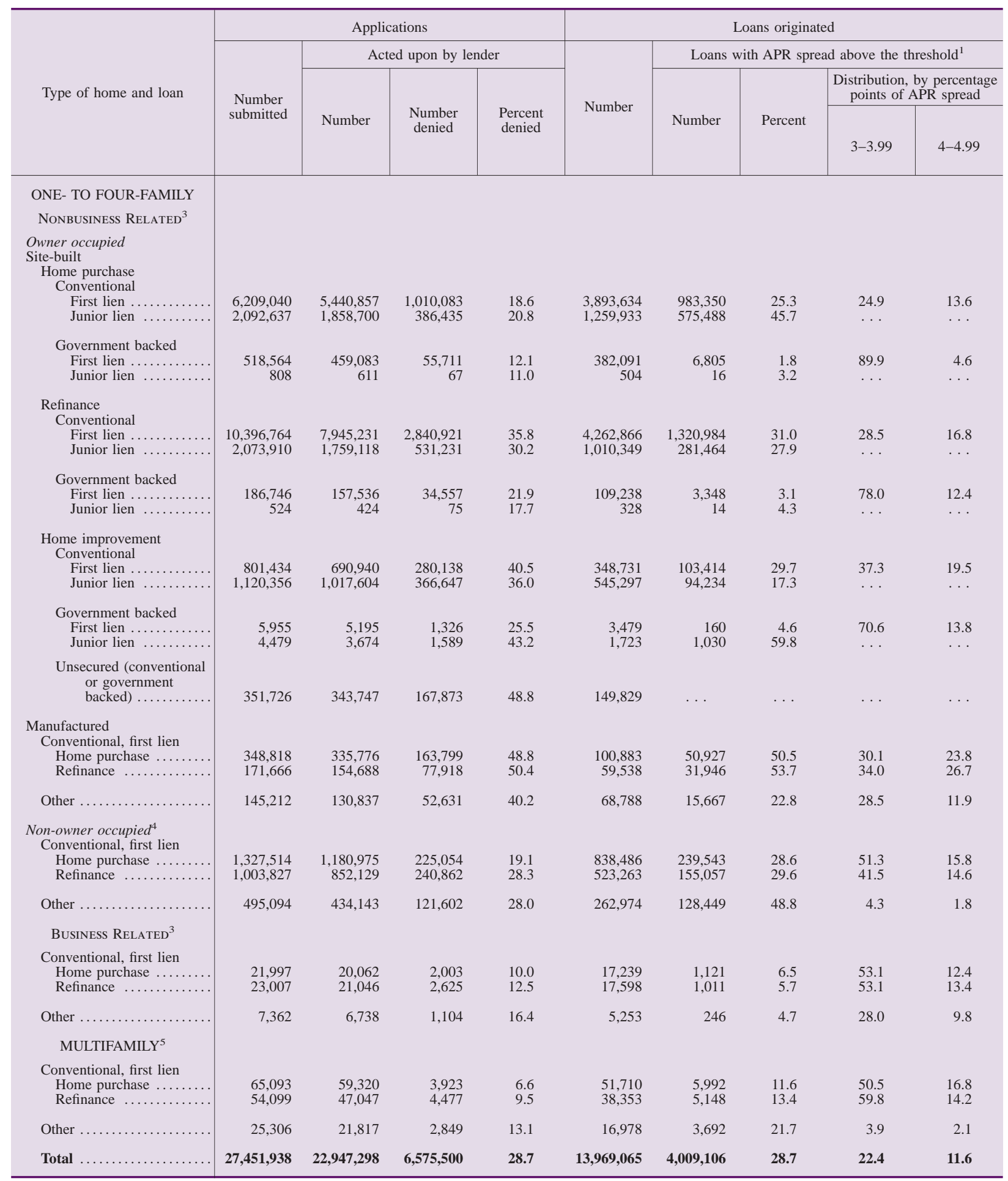

NoTE: Excludes transition-period applications (those submitted before 2004) and transition-period loans (those for which the application was submitted before 2004).

1. Annual percentage rate (APR) spread is the difference between the APR on the loan and the yield on a comparable-maturity Treasury security. The threshold for first-lien loans is a spread of 3 percentage points; for junior-lien loans, it is a spread of 5 percentage points.

2. Loans covered by the Home Ownership and Equity Protection Act of 1994, which does not apply to home-purchase loans.
3. Business-related applications and loans are those for which the lender reported that the race, ethnicity, and sex of the applicant or co-applicant are not applicable; all other applications and loans are nonbusiness related.

4. Includes applications and loans for which occupancy status was missing.

5. Includes business-related and nonbusiness-related applications and loans for owner-occupied and non-owner-occupied properties.

... Not applicable. 
4. Disposition of applications for home loans, and origination and pricing of loans, by type of home and type of loan, 2006-Continued

\begin{tabular}{|c|c|c|c|c|c|c|c|c|c|c|c|}
\hline \multicolumn{6}{|c|}{ Loans originated } & \multirow{2}{*}{\multicolumn{6}{|c|}{$\begin{array}{l}\text { MEMO } \\
\text { Transition-period applications (those submitted before 2004) }\end{array}$}} \\
\hline \multicolumn{6}{|c|}{ Loans with APR spread above the threshold ${ }^{1}$} & & & & & & \\
\hline $\begin{array}{r}\text { Dist } 1 \\
\text { p }\end{array}$ & $\begin{array}{l}\text { ion, by } p \\
\text { of APR }\end{array}$ & $\begin{array}{l}\text { tage } \\
\text { d }\end{array}$ & $\begin{array}{r}\mathrm{AP} \\
\text { (percer }\end{array}$ & $\begin{array}{l}\text { read } \\
\text { points) }\end{array}$ & Number of & \multirow[b]{2}{*}{$\begin{array}{l}\text { Number } \\
\text { submitted }\end{array}$} & \multirow[b]{2}{*}{$\begin{array}{c}\text { Number } \\
\text { denied }\end{array}$} & \multirow[b]{2}{*}{$\begin{array}{l}\text { Percent } \\
\text { denied }\end{array}$} & \multicolumn{2}{|c|}{ Loans originated } & \multirow{2}{*}{$\begin{array}{c}\text { Number of } \\
\text { HOEPA- } \\
\text { covered } \\
\text { loans }^{2}\end{array}$} \\
\hline $5-6.99$ & $7-8.99$ & $\begin{array}{l}9 \text { or } \\
\text { more }\end{array}$ & Mean & Median & $\begin{array}{l}\text { HOEPA- } \\
\text { covered } \\
\text { loans }^{2}\end{array}$ & & & & Number & $\begin{array}{c}\text { Percent with } \\
\text { APR spread } \\
\text { above } \\
\text { threshold }\end{array}$ & \\
\hline $\begin{array}{l}51.5 \\
58.9\end{array}$ & $\begin{array}{r}9.6 \\
37.2\end{array}$ & $\begin{array}{r}.5 \\
4.0\end{array}$ & $\begin{array}{l}5.3 \\
6.8\end{array}$ & $\begin{array}{l}5.5 \\
6.7\end{array}$ & $\ldots$ & $\begin{array}{r}1,875 \\
69\end{array}$ & $\begin{array}{r}123 \\
4\end{array}$ & $\begin{array}{r}11.0 \\
8.9\end{array}$ & $\begin{array}{r}527 \\
23\end{array}$ & $\begin{array}{r}3.6 \\
17.4\end{array}$ & $\ldots$ \\
\hline $\begin{array}{r}2.8 \\
75.0\end{array}$ & $\begin{array}{r}2.4 \\
25.0\end{array}$ & $\begin{array}{l}.3 \\
.0\end{array}$ & $\begin{array}{l}3.5 \\
6.2\end{array}$ & $\begin{array}{l}3.2 \\
6.3\end{array}$ & $\begin{array}{l}\ldots \\
\ldots\end{array}$ & $\begin{array}{r}129 \\
0\end{array}$ & $\begin{array}{r}10 \\
0\end{array}$ & $\begin{array}{c}20.0 \\
0\end{array}$ & $\begin{array}{r}17 \\
0\end{array}$ & $\begin{array}{c}17.6 \\
0\end{array}$ & $\begin{array}{l}\ldots \\
\ldots\end{array}$ \\
\hline $\begin{array}{l}44.9 \\
55.5\end{array}$ & $\begin{array}{r}9.7 \\
37.1\end{array}$ & $\begin{array}{r}.1 \\
7.5\end{array}$ & $\begin{array}{l}5.1 \\
6.9\end{array}$ & $\begin{array}{l}5.2 \\
6.8\end{array}$ & $\begin{array}{l}3,894 \\
2,655\end{array}$ & $\begin{array}{r}2,472 \\
33\end{array}$ & $\begin{array}{r}84 \\
2\end{array}$ & $\begin{array}{r}7.2 \\
10.5\end{array}$ & $\begin{array}{r}93 \\
6\end{array}$ & $\begin{array}{l}4.3 \\
0\end{array}$ & $\begin{array}{l}0 \\
0\end{array}$ \\
\hline $\begin{array}{r}7.8 \\
42.9\end{array}$ & $\begin{array}{r}1.7 \\
42.9\end{array}$ & $\begin{array}{r}.1 \\
14.3\end{array}$ & $\begin{array}{l}3.7 \\
7.0\end{array}$ & $\begin{array}{l}3.2 \\
7.3\end{array}$ & $\begin{array}{r}16 \\
0\end{array}$ & $\begin{array}{r}80 \\
0\end{array}$ & $\begin{array}{r}12 \\
0\end{array}$ & $\begin{array}{c}21.4 \\
0\end{array}$ & $\begin{array}{r}11 \\
0\end{array}$ & $\begin{array}{l}9.1 \\
0\end{array}$ & $\begin{array}{l}0 \\
0\end{array}$ \\
\hline $\begin{array}{l}34.3 \\
46.7\end{array}$ & $\begin{array}{r}8.0 \\
35.1\end{array}$ & $\begin{array}{r}.7 \\
18.2\end{array}$ & $\begin{array}{l}4.9 \\
7.4\end{array}$ & $\begin{array}{l}4.6 \\
7.2\end{array}$ & $\begin{array}{l}1,578 \\
3,720\end{array}$ & $\begin{array}{r}8 \\
14\end{array}$ & $\begin{array}{l}0 \\
0\end{array}$ & $\begin{array}{l}0 \\
0\end{array}$ & $\begin{array}{l}3 \\
1\end{array}$ & $\begin{array}{l}0 \\
0\end{array}$ & $\begin{array}{l}0 \\
0\end{array}$ \\
\hline $\begin{array}{l}12.5 \\
41.7\end{array}$ & $\begin{array}{r}2.5 \\
33.0\end{array}$ & $\begin{array}{r}.6 \\
25.3\end{array}$ & $\begin{array}{l}3.9 \\
7.7\end{array}$ & $\begin{array}{l}3.5 \\
7.3\end{array}$ & $\begin{array}{r}1 \\
99\end{array}$ & $\begin{array}{l}1 \\
0\end{array}$ & $\begin{array}{l}0 \\
0\end{array}$ & $\begin{array}{l}0 \\
0\end{array}$ & $\begin{array}{l}0 \\
0\end{array}$ & $\begin{array}{l}0 \\
0\end{array}$ & $\begin{array}{l}0 \\
0\end{array}$ \\
\hline$\cdots$ & $\cdots$ & $\cdots$ & $\cdots$ & .. & $\cdots$ & 0 & 0 & 0 & 0 & 0 & .. \\
\hline $\begin{array}{l}30.2 \\
28.7\end{array}$ & $\begin{array}{r}12.0 \\
8.6\end{array}$ & $\begin{array}{l}3.9 \\
2.0\end{array}$ & $\begin{array}{l}5.3 \\
4.9\end{array}$ & $\begin{array}{l}4.8 \\
4.6\end{array}$ & 1,384 & $\begin{array}{l}32 \\
50\end{array}$ & $\begin{array}{l}1 \\
3\end{array}$ & $\begin{array}{r}5.9 \\
13.0\end{array}$ & $\begin{array}{l}6 \\
2\end{array}$ & $\begin{array}{c}0 \\
50.0\end{array}$ & 0 \\
\hline 23.8 & 23.8 & 12.0 & 6.1 & 5.6 & 1,023 & 8 & 1 & 25.0 & 2 & 0 & 0 \\
\hline $\begin{array}{l}25.8 \\
35.0\end{array}$ & $\begin{array}{l}6.3 \\
8.4\end{array}$ & $\begin{array}{l}.7 \\
.5\end{array}$ & $\begin{array}{l}4.6 \\
4.9\end{array}$ & $\begin{array}{l}3.9 \\
4.5\end{array}$ & 347 & $\begin{array}{l}369 \\
235\end{array}$ & $\begin{array}{r}12 \\
5\end{array}$ & $\begin{array}{l}5.6 \\
4.8\end{array}$ & $\begin{array}{l}83 \\
18\end{array}$ & $\begin{array}{l}7.2 \\
5.6\end{array}$ & 0 \\
\hline 35.0 & 34.2 & 24.6 & 7.6 & 7.4 & 276 & 16 & 2 & 18.2 & 7 & 42.9 & 0 \\
\hline $\begin{array}{l}30.4 \\
30.7\end{array}$ & $\begin{array}{l}3.8 \\
2.7\end{array}$ & $\begin{array}{l}.3 \\
.2\end{array}$ & $\begin{array}{l}4.5 \\
4.4\end{array}$ & $\begin{array}{l}3.9 \\
3.9\end{array}$ & $\cdots_{2}$ & $\begin{array}{l}7 \\
4\end{array}$ & $\begin{array}{l}0 \\
0\end{array}$ & $\begin{array}{l}0 \\
0\end{array}$ & $\begin{array}{l}6 \\
3\end{array}$ & $\begin{array}{l}0 \\
0\end{array}$ & $\ddot{0}$ \\
\hline 44.3 & 14.6 & 3.3 & 5.4 & 5.3 & 1 & 3 & 0 & 0 & 2 & 0 & 0 \\
\hline $\begin{array}{l}18.7 \\
19.7\end{array}$ & $\begin{array}{r}12.1 \\
5.9\end{array}$ & $\begin{array}{r}1.9 \\
.4\end{array}$ & $\begin{array}{l}4.8 \\
4.3\end{array}$ & $\begin{array}{l}4.0 \\
3.7\end{array}$ & 35 & $\begin{array}{l}175 \\
449\end{array}$ & $\begin{array}{r}11 \\
2\end{array}$ & $\begin{array}{l}7.1 \\
0.9\end{array}$ & $\begin{array}{l}109 \\
191\end{array}$ & $\begin{array}{l}2.8 \\
1.0\end{array}$ & $\ddot{0}$ \\
\hline 49.1 & 31.6 & 13.3 & 6.9 & 6.7 & 141 & 40 & 7 & 28.0 & 8 & 0 & 0 \\
\hline 46.6 & 16.7 & 2.7 & 5.6 & 5.7 & 15,172 & 6,069 & 279 & 8.6 & 1,118 & 4.2 & 0 \\
\hline
\end{tabular}

the share of non-owner-occupant lending among firstlien loans to purchase one- to four-family site-built homes began rising in 1994, and it has risen in every year between 1996 (when it was 6.4 percent) and 2005, when it reached 17.3 percent (table 8). For
2006, the share fell somewhat, to 16.5 percent. Further, in line with the experience for home-purchase loans to owner-occupants, the number of conventional first-lien loans to purchase homes by nonowner-occupants fell about 17 percent from 2005. 
5. Home-purchase lending that began with a request for pre-approval: Disposition and pricing, by type of home, 2006

\begin{tabular}{|c|c|c|c|c|c|c|c|c|c|}
\hline \multirow{3}{*}{ Type of home } & \multicolumn{3}{|c|}{ Requests for pre-approval } & \multicolumn{3}{|c|}{$\begin{array}{l}\text { Applications preceded by requests } \\
\text { for pre-approval }{ }^{1}\end{array}$} & \multicolumn{3}{|c|}{$\begin{array}{l}\text { Loan originations whose applications were } \\
\text { preceded by requests for pre-approval }\end{array}$} \\
\hline & \multirow{2}{*}{$\begin{array}{l}\text { Number } \\
\text { acted upon } \\
\text { by lender }\end{array}$} & \multirow{2}{*}{$\begin{array}{c}\text { Number } \\
\text { denied }\end{array}$} & \multirow{2}{*}{$\begin{array}{l}\text { Percent } \\
\text { denied }\end{array}$} & \multirow{2}{*}{$\begin{array}{l}\text { Number } \\
\text { submitted }\end{array}$} & \multicolumn{2}{|c|}{ Acted upon by lender } & \multirow{2}{*}{ Number } & \multicolumn{2}{|c|}{$\begin{array}{l}\text { Loans with APR spread } \\
\text { above the threshold }{ }^{2}\end{array}$} \\
\hline & & & & & Number & $\begin{array}{l}\text { Number } \\
\text { denied }\end{array}$ & & Number & Percent \\
\hline \multicolumn{10}{|l|}{$\begin{array}{l}\text { ONE- TO FOUR-FAMILY } \\
\text { NONBUSINESS RELATED }^{3}\end{array}$} \\
\hline \multicolumn{10}{|l|}{$\begin{array}{l}\text { Site-built } \\
\text { Conventional }\end{array}$} \\
\hline $\begin{array}{l}\text { First lien } \ldots \ldots \ldots \ldots \\
\text { Junior lien ................ }\end{array}$ & $\begin{array}{l}782,978 \\
158,359\end{array}$ & $\begin{array}{r}192,997 \\
37,834\end{array}$ & $\begin{array}{l}24.6 \\
23.9\end{array}$ & $\begin{array}{l}478,986 \\
103,306\end{array}$ & $\begin{array}{r}417,401 \\
92,200\end{array}$ & $\begin{array}{r}35,416 \\
7,924\end{array}$ & $\begin{array}{r}344,575 \\
72,364\end{array}$ & $\begin{array}{l}33,668 \\
19,054\end{array}$ & $\begin{array}{r}9.8 \\
26.3\end{array}$ \\
\hline $\begin{array}{l}\text { Government backed } \\
\text { First lien } \ldots \ldots \ldots \\
\text { Junior lien } \ldots \ldots \ldots\end{array}$ & $\begin{array}{r}77,970 \\
58\end{array}$ & $\begin{array}{r}22,654 \\
8\end{array}$ & $\begin{array}{l}29.1 \\
13.8\end{array}$ & $\begin{array}{r}55,250 \\
54\end{array}$ & $\begin{array}{r}48,701 \\
48\end{array}$ & $\begin{array}{r}3,996 \\
5\end{array}$ & $\begin{array}{r}42,201 \\
42\end{array}$ & $\begin{array}{r}1,063 \\
3\end{array}$ & $\begin{array}{l}2.5 \\
7.1\end{array}$ \\
\hline $\begin{array}{l}\text { Manufactured } \\
\quad \text { Conventional, first lien ... } \\
\text { Other } \ldots \ldots \ldots \ldots \ldots \ldots . . . . . .\end{array}$ & $\begin{array}{r}40,506 \\
5,079\end{array}$ & $\begin{array}{r}20,489 \\
1,533\end{array}$ & $\begin{array}{l}50.6 \\
30.2\end{array}$ & $\begin{array}{r}37,589 \\
3,811\end{array}$ & $\begin{array}{r}33,069 \\
3,117\end{array}$ & $\begin{array}{r}18,032 \\
515\end{array}$ & $\begin{array}{l}8,357 \\
2,452\end{array}$ & $\begin{array}{r}5,793 \\
149\end{array}$ & $\begin{array}{r}69.3 \\
6.1\end{array}$ \\
\hline $\begin{array}{l}\text { Non-owner occupied }{ }^{4} \\
\text { Conventional, first lien ... } \\
\text { Other .................. }\end{array}$ & $\begin{array}{l}89,459 \\
16,448\end{array}$ & $\begin{array}{r}17,789 \\
3,246\end{array}$ & $\begin{array}{l}19.9 \\
19.7\end{array}$ & $\begin{array}{l}67,177 \\
13,714\end{array}$ & $\begin{array}{l}57,720 \\
11,573\end{array}$ & $\begin{array}{l}7,102 \\
1,591\end{array}$ & $\begin{array}{r}44,834 \\
8,318\end{array}$ & $\begin{array}{l}8,890 \\
4,352\end{array}$ & $\begin{array}{l}19.8 \\
52.3\end{array}$ \\
\hline \multicolumn{10}{|l|}{ Business ReLated ${ }^{3}$} \\
\hline $\begin{array}{l}\text { Conventional, first lien } \ldots \\
\text { Other } \ldots \ldots \ldots \ldots \ldots \ldots \ldots\end{array}$ & $\begin{array}{r}2,976 \\
388\end{array}$ & $\begin{array}{r}198 \\
31\end{array}$ & $\begin{array}{l}6.7 \\
8.0\end{array}$ & $\begin{array}{r}2,813 \\
368\end{array}$ & $\begin{array}{r}2,370 \\
265\end{array}$ & $\begin{array}{r}126 \\
23\end{array}$ & $\begin{array}{r}2,161 \\
192\end{array}$ & $\begin{array}{l}84 \\
70\end{array}$ & $\begin{array}{r}3.9 \\
36.5\end{array}$ \\
\hline \multicolumn{10}{|l|}{ MULTIFAMILY 5} \\
\hline $\begin{array}{l}\text { Conventional, first lien } \ldots \ldots \\
\text { Other } \ldots \ldots \ldots \ldots \ldots \ldots \ldots\end{array}$ & $\begin{array}{l}295 \\
126\end{array}$ & $\begin{array}{r}30 \\
5\end{array}$ & $\begin{array}{r}10.2 \\
4.0\end{array}$ & $\begin{array}{l}275 \\
125\end{array}$ & $\begin{array}{l}240 \\
107\end{array}$ & $\begin{array}{r}18 \\
4\end{array}$ & $\begin{array}{r}212 \\
99\end{array}$ & $\begin{array}{r}44 \\
8\end{array}$ & $\begin{array}{r}20.8 \\
8.1\end{array}$ \\
\hline Total . & $1,174,642$ & 296,814 & 25.3 & 763,468 & 666,811 & 74,752 & 525,807 & 73,178 & 13.9 \\
\hline
\end{tabular}

NoTE: Excludes transition-period requests for pre-approval (those submitted before 2004). Refer to general note to table 1.

1. These applications are included in the total of $27,451,938$ reported in table 4.

2. Refer to table 4 , note 1 .

\section{Piggyback Lending}

Many first-time homebuyers have relatively limited assets and thus cannot qualify for other than a mortgage with a high loan-to-value ratio. Other borrowers have the financial capacity to make a large down payment but prefer not to do so. Lenders and secondary-market purchasers often require loans with high LTV ratios to be protected with private mortgage insurance (PMI), carried at the expense of the borrower, to indemnify them, at least in part, against the elevated risk of default on such loans.

In recent years, so-called piggyback loans have emerged as an alternative to PMI. In piggyback lending, borrowers simultaneously receive a first mortgage and a junior-lien (piggyback) loan. The piggyback loan finances the portion of the purchase price not being financed by the first mortgage and sometimes any cash payment that might have been made; the junior loan may amount to as much as
3. Business-related applications and loans are those for which the lender reported that the race, ethnicity, and sex of the applicant or co-applicant are "not applicable"; all other applications and loans are nonbusiness related.

4. Includes applications and loans for which occupancy status was missing.

5. Includes business-related and nonbusiness-related applications and loans for owner-occupied and non-owner-occupied properties.

... Not applicable.

20 percent of the purchase price. Some borrowers have chosen a piggyback loan instead of a loan backed by PMI in part because, until recently, borrower payments for PMI could not be itemized for federal income tax purposes, whereas the interest paid on piggyback loans could be. Also, without the piggyback loan, some home purchases might not have been possible because the underwriting standards applied by PMI companies may have been more conservative than those used by the lender providing the piggyback loan.

The expanded HMDA data document substantial growth in piggyback lending since 2004 and, together with data reported by PMI companies, suggest that such lending played an important role in home sales over the past few years. ${ }^{21}$ In 2006 , lenders covered by

21. Piggyback loans are not identified explicitly in the HMDA data. However, by matching junior-lien home-purchase loans with first-lien home-purchase loans extended at the same time to borrowers with the 
5. Home-purchase lending that began with a request for pre-approval: Disposition and pricing, by type of home, 2006-Continued

\begin{tabular}{|c|c|c|c|c|c|c|c|c|c|c|c|}
\hline \multicolumn{7}{|c|}{$\begin{array}{c}\text { Loan originations whose applications were } \\
\text { preceded by requests for pre-approval }\end{array}$} & \multicolumn{5}{|c|}{$\begin{array}{l}\text { MЕмо } \\
\text { Applications with transition-period requests for } \\
\text { pre-approval (request submitted before 2004) }\end{array}$} \\
\hline \multicolumn{5}{|c|}{ Distribution, by percentage points of APR spread } & \multicolumn{2}{|c|}{$\begin{array}{c}\text { APR spread } \\
\text { (percentage points) }\end{array}$} & \multirow[b]{2}{*}{$\begin{array}{l}\text { Number } \\
\text { submitted }\end{array}$} & \multirow[b]{2}{*}{$\begin{array}{c}\text { Number } \\
\text { denied }\end{array}$} & \multirow[b]{2}{*}{$\begin{array}{l}\text { Percent } \\
\text { denied }\end{array}$} & \multicolumn{2}{|c|}{ Loans originated } \\
\hline $3-3.99$ & $4-4.99$ & $5-6.99$ & $7-8.99$ & $\begin{array}{l}9 \text { or } \\
\text { more }\end{array}$ & $\begin{array}{l}\text { Mean } \\
\text { spread }\end{array}$ & $\begin{array}{l}\text { Median } \\
\text { spread }\end{array}$ & & & & Number & $\begin{array}{c}\text { Percent } \\
\text { with APR } \\
\text { spread above } \\
\text { threshold }\end{array}$ \\
\hline $\begin{array}{l}44.7 \\
\ldots\end{array}$ & $\begin{array}{l}17.3 \\
\ldots\end{array}$ & $\begin{array}{l}31.0 \\
58.1\end{array}$ & $\begin{array}{r}6.0 \\
34.1\end{array}$ & $\begin{array}{r}.9 \\
7.9\end{array}$ & $\begin{array}{l}4.7 \\
6.9\end{array}$ & $\begin{array}{l}4.3 \\
6.7\end{array}$ & $\begin{array}{r}35 \\
3\end{array}$ & $\begin{array}{l}2 \\
0\end{array}$ & $\begin{array}{l}8.7 \\
0\end{array}$ & $\begin{array}{r}14 \\
2\end{array}$ & $\begin{array}{l}0 \\
0\end{array}$ \\
\hline $\begin{array}{l}72.2 \\
\cdots\end{array}$ & $\begin{array}{l}18.8 \\
\ldots\end{array}$ & $\begin{array}{r}5.9 \\
66.7\end{array}$ & $\begin{array}{r}3.0 \\
33.3\end{array}$ & 0.1 & $\begin{array}{l}3.8 \\
6.2\end{array}$ & $\begin{array}{l}3.4 \\
6.4\end{array}$ & $\begin{array}{l}9 \\
0\end{array}$ & $\begin{array}{l}1 \\
0\end{array}$ & $\begin{array}{c}11.1 \\
0\end{array}$ & $\begin{array}{l}7 \\
0\end{array}$ & $\begin{array}{c}42.9 \\
0\end{array}$ \\
\hline $\begin{array}{l}20.0 \\
83.9\end{array}$ & $\begin{array}{r}24.4 \\
.7\end{array}$ & $\begin{array}{r}40.0 \\
3.4\end{array}$ & $\begin{array}{l}13.5 \\
12.1\end{array}$ & $\begin{array}{l}2.1 \\
0\end{array}$ & $\begin{array}{l}5.4 \\
3.8\end{array}$ & $\begin{array}{l}5.2 \\
3.3\end{array}$ & $\begin{array}{l}0 \\
0\end{array}$ & $\begin{array}{l}0 \\
0\end{array}$ & $\begin{array}{l}0 \\
0\end{array}$ & $\begin{array}{l}0 \\
0\end{array}$ & $\begin{array}{l}0 \\
0\end{array}$ \\
\hline $\begin{array}{c}60.0 \\
0\end{array}$ & $\begin{array}{c}18.0 \\
0\end{array}$ & $\begin{array}{l}16.6 \\
22.8\end{array}$ & $\begin{array}{r}4.3 \\
36.1\end{array}$ & $\begin{array}{r}1.2 \\
41.2\end{array}$ & $\begin{array}{l}4.3 \\
8.6\end{array}$ & $\begin{array}{l}3.7 \\
8.5\end{array}$ & $\begin{array}{r}10 \\
3\end{array}$ & $\begin{array}{l}1 \\
0\end{array}$ & $\begin{array}{c}16.7 \\
0\end{array}$ & $\begin{array}{l}5 \\
1\end{array}$ & $\begin{array}{l}0 \\
0\end{array}$ \\
\hline $\begin{array}{r}60.7 \\
1.4\end{array}$ & $\begin{array}{l}7.1 \\
1.4\end{array}$ & $\begin{array}{l}17.9 \\
37.1\end{array}$ & $\begin{array}{l}11.9 \\
31.4\end{array}$ & $\begin{array}{r}2.4 \\
28.6\end{array}$ & $\begin{array}{l}4.6 \\
7.8\end{array}$ & $\begin{array}{l}3.5 \\
7.7\end{array}$ & $\begin{array}{l}3 \\
0\end{array}$ & $\begin{array}{l}0 \\
0\end{array}$ & $\begin{array}{l}0 \\
0\end{array}$ & $\begin{array}{l}1 \\
0\end{array}$ & $\begin{array}{l}0 \\
0\end{array}$ \\
\hline $\begin{array}{l}47.7 \\
12.5\end{array}$ & $\begin{array}{c}18.2 \\
0\end{array}$ & $\begin{array}{l}27.3 \\
62.5\end{array}$ & $\begin{array}{r}4.5 \\
12.5\end{array}$ & $\begin{array}{r}2.3 \\
12.5\end{array}$ & $\begin{array}{l}4.6 \\
7.6\end{array}$ & $\begin{array}{l}4.2 \\
6.2\end{array}$ & $\begin{array}{l}0 \\
0\end{array}$ & $\begin{array}{l}0 \\
0\end{array}$ & $\begin{array}{l}0 \\
0\end{array}$ & $\begin{array}{l}0 \\
0\end{array}$ & $\begin{array}{l}0 \\
0\end{array}$ \\
\hline 30.8 & 12.4 & 36.1 & 15.5 & 5.3 & 5.5 & 5.3 & 63 & 4 & 9.1 & 30 & 10.0 \\
\hline
\end{tabular}

HMDA reported on 1.43 million junior-lien loans to purchase homes; almost all of them were conventional loans, and the quantity was about 4 percent greater than in 2005 (data not shown in tables). Almost 24 percent of the 2006 first-lien conventional home-purchase loans on owner-occupied site-built homes for one to four families involved a piggyback loan as identified here, a proportion that was 2.7 percentage points higher than the comparable figure for 2005. The overall increase from 2005 to 2006 in the number of reported junior-lien loans used to finance a home purchase is notable because the number of reported conventional first-lien home-purchase loans fell nearly 12 percent from 2005 to 2006 . Further, in 2006 piggyback lending apparently continued to gain market share at the expense of PMI, as the number of home-purchase loans backed by PMI declined about 6 percent from 2005 to 2006.22

same characteristics and census tract location, an estimate of the incidence of piggyback loans, at least for those originated by the same lender, can be derived. About 85 percent of junior-lien loans reported in the HMDA data can be matched in this manner.

22. Annual PMI data are published by the FFIEC and are available at www.ffiec.gov.
An individual whose loan request is too large to meet the conforming size limits also has a reason to take out a piggyback loan: It can be used to divide the total loan amount so that the size of the first lien will be conforming. We estimate that in 2006, 9.6 percent of piggyback loans were used for that purpose (down from 10.1 percent in 2005). Looked at from the borrower perspective, of the individuals in 2006 who borrowed a total exceeding the conforming loan amount, 17.8 percent used a piggyback loan to create a first lien with a conforming size (up from 13.6 percent in 2005).

\section{Manufactured-Home Lending}

Manufactured homes, which often sell for less than site-built homes, are an important option for many homebuyers. ${ }^{23}$ However, the credit risks associated with manufactured-home lending also tend to be higher than for site-built homes, so loans backed by manufactured units carry relatively high interest rates.

23. Unlike site-built homes, manufactured homes are generally assembled in factories and shipped to a home site. 
6. Cumulative distribution of home loans, by loan amount and by purpose, type, and pricing of loan, 2006 Percent

\begin{tabular}{|c|c|c|c|c|c|c|c|c|c|c|}
\hline \multirow{3}{*}{$\begin{array}{l}\text { Upper bound of } \\
\text { loan amount } \\
\text { (thousands } \\
\text { of dollars) })^{1}\end{array}$} & \multicolumn{5}{|c|}{ Home purchase } & \multicolumn{5}{|c|}{ Refinance } \\
\hline & \multicolumn{3}{|c|}{ Conventional } & \multirow[b]{2}{*}{ FHA } & \multirow[b]{2}{*}{ VA } & \multicolumn{3}{|c|}{ Conventional } & \multirow[b]{2}{*}{ FHA } & \multirow[b]{2}{*}{ VA } \\
\hline & $\begin{array}{l}\text { Not higher } \\
\text { priced }\end{array}$ & $\begin{array}{l}\text { Higher } \\
\text { priced }\end{array}$ & Total & & & $\begin{array}{l}\text { Not higher } \\
\text { priced }\end{array}$ & $\begin{array}{l}\text { Higher } \\
\text { priced }\end{array}$ & Total & & \\
\hline 24 & .3 & .6 & .4 & .1 & .0 & .9 & 1.3 & 1.0 & .1 & .2 \\
\hline 49 & 1.9 & 3.4 & 2.3 & 2.5 & .5 & 3.9 & 4.7 & 4.1 & 2.1 & 3.3 \\
\hline 74 & 6.6 & 12.6 & 8.1 & 12.9 & 3.2 & 9.8 & 12.9 & 10.8 & 9.7 & 12.2 \\
\hline 99 : & $\begin{array}{l}0.0 \\
13.6\end{array}$ & 23.3 & $\begin{array}{r}0.1 \\
16.0\end{array}$ & 30.1 & $\begin{array}{r}30.7 \\
10.7\end{array}$ & $\begin{array}{r}9.0 \\
17.1\end{array}$ & 22.8 & $\begin{array}{l}18.0 \\
18.9\end{array}$ & 23.4 & 25.6 \\
\hline $124^{\circ}$ & $\begin{array}{l}23.0 \\
23.7\end{array}$ & 34.6 & 26.5 & $\begin{array}{l}3.1 \\
48.4\end{array}$ & 21.6 & $\begin{array}{l}11.1 \\
26.2\end{array}$ & 33.6 & 28.5 & 40.0 & 40.0 \\
\hline 149 & 34.5 & 44.6 & 37.1 & 67.4 & 36.7 & 34.7 & 43.5 & 37.4 & 57.5 & 55.3 \\
\hline 174 & 43.9 & 52.9 & 46.2 & 81.3 & 52.0 & 43.4 & 52.5 & 46.2 & 71.4 & 67.0 \\
\hline 199 & 51.9 & 59.9 & 54.0 & 90.0 & 64.7 & 50.7 & 60.0 & 53.6 & 81.4 & 76.2 \\
\hline 224 & 59.5 & 66.2 & 61.2 & 94.4 & 74.0 & 58.0 & 66.7 & 60.7 & 88.4 & 83.2 \\
\hline 249 & 65.2 & 71.3 & 66.7 & 96.8 & 81.8 & 63.5 & 71.8 & 66.1 & 92.3 & 88.5 \\
\hline 274 & 70.3 & 75.5 & 71.6 & 98.1 & 87.3 & 68.8 & $\begin{array}{l}1.0 \\
76.3\end{array}$ & 71.1 & 94.9 & $\begin{array}{l}0.0 \\
92.4\end{array}-4$ \\
\hline 299 & 74.4 & 79.3 & 75.6 & 98.8 & 91.3 & 72.9 & 79.9 & 75.0 & 96.5 & 94.9 \\
\hline 324 & 78.4 & 82.7 & 79.5 & 99.2 & 94.2 & 77.0 & 83.3 & 79.0 & 97.6 & 96.8 \\
\hline 349 & 81.3 & 85.3 & 82.3 & 99.5 & 96.2 & 80.0 & 85.9 & 81.8 & 98.4 & 97.9 \\
\hline 374 & 84.0 & 87.7 & 84.9 & 99.8 & 97.6 & 83.0 & 88.2 & 84.6 & 99.6 & 98.8 \\
\hline 399 & $\begin{array}{l}8.0 \\
86.1\end{array}$ & 89.6 & 87.0 & 99.8 & 98.7 & $\begin{array}{l}85.3 \\
85.3\end{array}$ & $\begin{array}{l}0.2 \\
90.0\end{array}$ & $\begin{array}{l}8.0 \\
86.7\end{array}$ & 99.7 & 99.4 \\
\hline 417 & 89.1 & 91.0 & 89.6 & 99.9 & 99.6 & 88.5 & 91.4 & 89.4 & 99.8 & 99.9 \\
\hline 449 & 90.2 & 92.8 & 90.9 & 99.9 & 99.7 & 89.8 & 93.1 & 90.8 & 99.9 & 99.9 \\
\hline 499 & 92.2 & 95.1 & 92.9 & 100 & 99.8 & 92.1 & 95.2 & 93.1 & 100 & 99.9 \\
\hline 549 & 94.0 & 96.7 & 94.7 & 100 & 99.9 & 94.0 & 96.7 & 94.9 & 100 & 100 \\
\hline 599 & 95.2 & 97.7 & 95.8 & 100 & 100 & 95.3 & 97.6 & 96.0 & 100 & 100 \\
\hline 649 & 96.3 & 98.4 & 96.8 & 100 & 100 & 96.4 & 98.3 & 97.0 & 100 & 100 \\
\hline 699 & 97.0 & 98.8 & 97.5 & 100 & 100 & 97.2 & 98.8 & 97.7 & 100 & 100 \\
\hline 749 & 97.5 & 99.1 & 97.9 & 100 & 100 & 97.6 & 99.0 & 98.1 & 100 & 100 \\
\hline 799 …… & 97.9 & 99.3 & 98.3 & 100 & 100 & 98.0 & 99.3 & 98.4 & 100 & 100 \\
\hline More than 799 & 100 & 100 & 100 & 100 & 100 & 100 & 100 & 100 & 100 & 100 \\
\hline \multicolumn{11}{|l|}{$\begin{array}{l}\text { MEMO } \\
\text { Loan amount } \\
\text { (thousands } \\
\text { of dollars) }\end{array}$} \\
\hline Mean ........ & 245.8 & 208.7 & 236.4 & 133.0 & 184.6 & 245.6 & 207.5 & 233.8 & 150.2 & 154.1 \\
\hline Median ${ }^{1}$ & 192 & 165 & 185 & 127 & 171 & 196 & 167 & 186 & 138 & 141 \\
\hline
\end{tabular}

1. Loan amounts are reported under HMDA to the nearest $\$ 1,000$. FHA Federal Housing Administration.

VA Department of Veterans Affairs.

Beginning with the 2004 data, HMDA rules require lenders to include a code to identify applications and loans involving manufactured homes. ${ }^{24}$ The 2006 data indicate that 4,477 lenders extended about 256,000 manufactured-home loans, a loan volume little changed from 2005 (data not shown in tables). Despite the large number of lenders extending at least one mortgage for a manufactured home, such lending is relatively concentrated: 83 percent of the reported manufactured home loans were reported by just ten lenders. About three-fifths of reported manufacturedhome loans were used to purchase homes, and a relatively large portion of those mortgages were FHA-insured (18 percent, versus about 5 percent on the purchase of site-built homes).

Delinquency rates on manufactured homes tend to be higher than for other types of home loans, and the

24. In the years preceding 2004, the Department of Housing and Urban Development (HUD) helped users of the HMDA data identify, albeit imperfectly, applications and loans related to manufactured homes by producing each year a list of reporting institutions (typically about twenty) that it believed were primarily in the business of extending such credit (www.huduser.org/datasets/manu.html). resulting lender caution is reflected in very high rates of denial for home-purchase applications on such properties (table 4). (The elevated credit risk also is reflected in elevated loan prices, as discussed below.) Because the use of manufactured homes varies greatly across populations and geographies, analyses of denial-rate differences across groups should differentiate between site-built and manufactured housing.

\section{Loans Covered by HOEPA}

Under the Home Ownership Equity Protection Act of 1994, certain types of mortgage loans that have rates or fees above specified levels require additional disclosures to consumers and are subject to certain restrictions on loan terms. ${ }^{25}$ Under the 2002 revisions to Regulation $\mathrm{C}$, the expanded HMDA data include a code to identify whether a loan is subject to the protections of HOEPA.

25. HOEPA is implemented by the Federal Reserve Board's Regulation Z (www.federalreserve.gov/regulations/default.htm). 
7. Cumulative distribution of home loans, by borrower income and by purpose, type, and pricing of loan, 2006 Percent

\begin{tabular}{|c|c|c|c|c|c|c|c|c|c|c|}
\hline \multirow{3}{*}{$\begin{array}{l}\text { Upper bound of } \\
\text { borrower income } \\
\text { (thousands } \\
\text { of dollars) }\end{array}$} & \multicolumn{5}{|c|}{ Home purchase } & \multicolumn{5}{|c|}{ Refinance } \\
\hline & \multicolumn{3}{|c|}{ Conventional } & \multirow{2}{*}{ FHA } & \multirow{2}{*}{ VA } & \multicolumn{3}{|c|}{ Conventional } & \multirow{2}{*}{ FHA } & \multirow{2}{*}{ VA } \\
\hline & $\begin{array}{l}\text { Not higher } \\
\text { priced }\end{array}$ & $\begin{array}{l}\text { Higher } \\
\text { priced }\end{array}$ & Total & & & $\begin{array}{l}\text { Not higher } \\
\text { priced }\end{array}$ & $\begin{array}{l}\text { Higher } \\
\text { priced }\end{array}$ & Total & & \\
\hline 24 & 2.9 & 3.6 & 3.1 & 5.9 & 1.0 & 2.9 & 4.6 & 3.5 & 4.6 & 3.0 \\
\hline 49 & 22.5 & 29.3 & 24.2 & 50.6 & 31.0 & 23.1 & 33.0 & 26.2 & 39.5 & 31.4 \\
\hline 74 & 46.3 & 56.1 & 48.8 & 83.2 & 69.2 & 48.8 & 62.3 & 53.0 & 76.3 & 69.4 \\
\hline 99 . & 64.8 & 73.9 & 67.1 & 94.5 & 89.2 & 68.1 & 79.8 & 71.8 & 93.1 & 88.5 \\
\hline 124 & 76.8 & 84.3 & 78.7 & 97.7 & 96.6 & 80.0 & 88.6 & 82.7 & 98.0 & 96.0 \\
\hline 149 & 83.8 & 89.9 & 85.4 & 98.7 & 98.8 & 86.5 & 92.8 & 88.5 & 99.3 & 98.6 \\
\hline 199 & 91.6 & 95.7 & 92.6 & 99.5 & 99.8 & 93.2 & 96.8 & 94.3 & 99.8 & 99.8 \\
\hline 249 & 94.9 & 97.6 & 95.6 & 99.7 & 99.9 & 96.0 & 98.2 & 96.6 & 99.9 & 100 \\
\hline $299 \ldots \ldots \ldots$ & 96.5 & 98.4 & 97.0 & 99.8 & 100 & 97.2 & 98.7 & 97.7 & 99.9 & 100 \\
\hline More than 299 & 100 & 100 & 100 & 100 & 100 & 100 & 100 & 100 & 100 & 100 \\
\hline \multicolumn{11}{|l|}{$\begin{array}{l}\text { MEMo } \\
\text { Borrower income, } \\
\text { by selected loan } \\
\text { type (thousands } \\
\text { of dollars) })^{2}\end{array}$} \\
\hline \multicolumn{11}{|l|}{ All } \\
\hline Mean ... & 105.3 & 86.1 & 100.5 & 55.2 & 66.0 & 98.6 & 78.1 & 92.1 & 60.1 & 65.8 \\
\hline Median $^{1}$ & 79 & 68 & 76 & 49 & 60 & 76 & 63 & 72 & 56 & 60 \\
\hline \multicolumn{11}{|l|}{ Conforming } \\
\hline Mean ....... & 85.3 & 74.0 & 82.4 & $\ldots$ & $\ldots$ & 80.9 & 67.8 & 76.7 & $\ldots$ & $\ldots$ \\
\hline $\operatorname{Median}^{1} \ldots$ & 72 & 64 & 70 & $\ldots$ & $\ldots$ & 70 & 60 & 66 & $\ldots$ & $\ldots$ \\
\hline \multicolumn{11}{|l|}{ Jumbo } \\
\hline Mean ... & 271.6 & 212.1 & 258.8 & $\ldots$ & $\ldots$ & 234.7 & 191.0 & 223.7 & $\ldots$ & \\
\hline Median $^{1}$ & 199 & 168 & 190 & & $\ldots$ & 175 & 150 & 168 & & . \\
\hline
\end{tabular}

Note: For loans with two or more applicants, HMDA-covered lenders report data on only two. Income for two applicants is reported jointly.

1. Income amounts are reported under HMDA to the nearest $\$ 1,000$.

2. By size, all loans backed by the FHA or VA are conforming.

... Not applicable.

FHA Federal Housing Administration. VA Department of Veterans Affairs.
Coverage under HOEPA is determined by a twopart test that considers both the APR and the dollar amount of points and fees. The APR portion of the coverage test is similar to that used to determine which loans are higher priced under HMDA. In the case of HMDA, identifying higher-priced loans re-

8. Non-owner-occupied lending as a share of all first liens to purchase one- to four-family site-built homes, by number and dollar amount of loans, 1990-2006

Percent

\begin{tabular}{|c|c|c|}
\hline Year & Number & Dollar amount \\
\hline 1990 . & 6.6 & 5.9 \\
\hline 1991 & $\begin{array}{l}5.0 \\
5.6\end{array}$ & 4.5 \\
\hline 1992 & 5.2 & 4.0 \\
\hline 1993. & 5.1 & 3.8 \\
\hline 1994. & 5.7 & 4.3 \\
\hline 1995. & 6.4 & 5.0 \\
\hline 1996. & 6.4 & 5.1 \\
\hline 1997. & 7.0 & 5.8 \\
\hline 1998 & 7.1 & 6.0 \\
\hline 1999 & 7.4 & 6.4 \\
\hline 2000 . & 8.0 & 7.2 \\
\hline 2001 & 8.6 & 7.6 \\
\hline 2002 & 10.5 & 9.2 \\
\hline 2003 & 11.9 & 10.6 \\
\hline 2004 & 14.9 & 13.1 \\
\hline 2005 . & 17.3 & 15.7 \\
\hline 2006 . & 16.5 & 14.8 \\
\hline
\end{tabular}

quires using the yield on the Treasury security of comparable maturity for the fifteenth day of the month preceding the date on which the loan rate was set. For HOEPA, however, the APR portion of the coverage test requires using the yield on the Treasury security of comparable maturity for the fifteenth day of the month preceding the month in which the application was received. Another difference is that the APR spreads for determining HOEPA coverage are higher than for determining which loans must be reported as higher-priced under HMDA. HOEPA coverage is based on spreads that exceed 8 percentage points and 10 percentage points for first- and juniorlien loans, respectively, versus minimum spreads of 3 percentage points and 5 percentage points, respectively, in HMDA higher-priced loans.

Before the release of the 2004 data, little information was publicly available about the extent of HOEPA-related lending or the number or type of institutions involved in that activity. Although the expanded HMDA data provide important new information, the data fail to capture all HOEPA-related lending. Some HOEPA loans are extended by institutions not covered by HMDA, and some HOEPA loans made by HMDA-covered institutions are not reported 
under Regulation C, which implements HMDA. Most notably, if the proceeds of a home-secured loan are not used to refinance an existing home loan or to finance home improvements, then the loan may be covered by HOEPA but is not reportable under Regulation $\mathrm{C}$. The extent of HOEPA-related lending not reported under HMDA is unknown.

For 2006, roughly 1,200 lenders reported extending about 15,200 loans covered by HOEPA (table 4). Only 17 lenders made 100 or more HOEPA loans, and most lenders did not report any such loans (data not shown in tables). A majority of the HOEPA loans involved a refinancing, and about two-thirds of these were first-lien loans. In the aggregate, HOEPArelated lending accounts for a very small proportion of the loan market: HOEPA loans accounted for less than 0.1 percent of all the originations of homesecured refinancings and home-improvement loans reported for 2006 (data derived from table 4).

\section{THE 2006 HMDA DATA ON LOAN PRICING}

The sections that follow analyze the loan-pricing information in the 2006 HMDA data by lender, loan product, geography, and characteristics of borrowers and their neighborhoods.

\section{Incidence of Higher-Priced Lending}

As with most loans reported in 2004 and 2005, most loans reported in 2006 were not higher-priced as defined under the Board's Regulation C. ${ }^{26}$ Among all the HMDA-reported loans, 28.7 percent were higherpriced in 2006, up from 26.2 percent in 2005 (table 4). Later sections of this article focus on the changes in the incidence of higher-priced lending from 2005 to 2006; this section focuses on 2006 pricing patterns across loan products.

The incidence of higher-priced lending in 2006 differed by loan product (table 4). For example,

- Loans backed by the government-either insured by the FHA or guaranteed by the VA- had a much lower incidence of higher-priced lending than did conventional loans used for the same purpose.

- First-lien home-purchase loans had a lower incidence of higher-priced lending than did junior-lien loans used for that purpose.

- Manufactured-home loans exhibited the greatest incidence of higher pricing regardless of purpose.

26. Refer to notes 5 and 6 and the appendix.
- First-lien home-purchase loans extended to nonowner occupants had a higher incidence of higherpriced lending than did comparable loans to owner occupants.

\section{Rate Spreads for Higher-Priced Lending}

The 2006 variation in APR spreads between homepurchase loans and loans used in refinancings was much smaller than the variations in incidence noted above. For example, for higher-priced conventional first-lien loans for an owner-occupied site-built home, the mean APR spreads were about 5 percentage points above the yields on comparable Treasury securities both for purchase loans and refinancings (table 4). A similar pattern is found for conventional junior-lien loans: They show a mean spread of about 7 percentage points whether they were used for home purchase or refinancing.

As noted, loans backed by manufactured homes were substantially more likely to be higher-priced than loans backed by site-built properties. However, for each of those two products, the mean spreads paid by those with higher-priced loans were roughly the same whether the loan was for home purchase or refinancing.

As in 2004 and 2005, only a relatively small proportion (about 10 percent) of first-lien loans in 2006 had very large spreads -7 percentage points or more. Similarly, only a relatively small proportion of junior-lien loans had spreads of 9 percentage points or more.

\section{Lenders and Higher-Priced Lending}

The concentration of higher-priced lending among institutions covered by HMDA fell somewhat in 2006, although it remained fairly high. About 5,000 of the nearly 8,900 lenders covered by HMDA in 2006 reported extending fewer than 10 higher-priced loans (data not shown in tables). At the other end of the spectrum, the roughly 1,250 lenders that reported making at least 100 higher-priced loans in 2006 accounted for 97 percent of all such loans. The share of such lending attributable to the 10 lenders with the largest volume of higher-priced loans dropped from 59 percent in 2005 to 35 percent in 2006.

Another aspect of concentration is the extent to which institutions that extend higher-priced loans may be considered to be "specialists" in that activity, that is, to have a large proportion of their loans in the higher-priced category. Such specialized institutions 
9. Higher-priced lending: Distribution by type of lender, and incidence at each type of lender, 2004-06 Percent

\begin{tabular}{|c|c|c|c|c|c|c|c|c|c|}
\hline \multirow{3}{*}{ Type of lender } & \multicolumn{3}{|c|}{2004} & \multicolumn{3}{|c|}{2005} & \multicolumn{3}{|c|}{2006} \\
\hline & \multicolumn{2}{|c|}{ Higher-priced loans } & \multirow{2}{*}{$\begin{array}{l}\text { Мемо: } \\
\text { All loans, } \\
\text { distribution }\end{array}$} & \multicolumn{2}{|c|}{ Higher-priced loans } & \multirow{2}{*}{$\begin{array}{l}\text { Мемо: } \\
\text { All loans, } \\
\text { distribution }\end{array}$} & \multicolumn{2}{|c|}{ Higher-priced loans } & \multirow{2}{*}{$\begin{array}{l}\text { MEмо: } \\
\text { All loans, } \\
\text { distribution }\end{array}$} \\
\hline & Distribution & Incidence & & Distribution & Incidence & & Distribution & Incidence & \\
\hline $\begin{array}{l}\text { Independent mortgage } \\
\text { company } \ldots \ldots \ldots . .\end{array}$ & 50.6 & 25.5 & 27.8 & 52.0 & 41.4 & 31.0 & 45.7 & 41.5 & 31.2 \\
\hline Depository ............. & 25.9 & 8.0 & 45.2 & 22.8 & 12.8 & 43.8 & 28.5 & 18.7 & 43.4 \\
\hline Subsidiary of depository & 11.5 & 9.0 & 17.9 & 13.0 & 20.7 & 15.5 & 12.4 & 22.9 & 15.4 \\
\hline Affiliate of depository .. & 12.0 & 18.6 & 9.1 & 12.2 & 30.9 & 9.7 & 13.4 & 37.9 & 10.1 \\
\hline Total & 100 & 14.0 & 100 & 100 & 24.7 & 100 & 100 & 28.4 & 100 \\
\hline
\end{tabular}

NoTE: Conventional, first-lien mortgages for site-built properties.

can have a business orientation that is quite different from that of other lenders. ${ }^{27}$ Taking 60 percent of loans as the criterion for defining higher-priced specialists, about 25 percent of the roughly 1,250 lenders reporting at least 100 higher-priced loans were specialists, or about 4 percent of all reporting institutions. The HMDA data on pricing can only approximately indicate the extent to which a lender specializes in subprime loans because some prime loans are higher-priced, and some subprime loans are not.

Higher-priced lending activity may also be described by type of lender. Four groupings are provided here-depository institutions and three types of mortgage company, namely, independents, direct subsidiaries of depository institutions, and affiliates of depository institutions. Regarding conventional firstlien loans for site-built homes in both 2004 and 2005, independent mortgage companies originated about 50 percent of the higher-priced loans and about 30 percent of all such loans; in contrast, depository institutions originated about 25 percent of the higherpriced loans and about 45 percent of all such loans (table 9).

The market shares for all types of home lending were virtually unchanged from 2005 to 2006 across the four categories of lender. However, some changes in market shares of higher-priced lending appeared across the four groups. Depository institutions increased their share of the higher-priced loan market about 6 percentage points, while the market share of independent mortgage companies fell about the same number of percentage points. Notably, the incidence of higher-priced lending for independent mortgage companies was unchanged from 2005, which suggests that the increase in market share for depositories was not caused by independent mortgage companies abandoning that segment of the market.

27. For example, specialists in higher-priced lending may use different marketing practices and may rely more heavily on the ability to sell loans to secondary-market purchasers.
The recent turmoil in the subprime sector has caused a number of lenders, primarily independent mortgage companies, to cease operations, curtail their activities, or transfer or sell their business to others. As a consequence, the 2007 HMDA data may reveal a notable change in the sources of higher-priced lending, likely with a diminished share coming from independent mortgage companies.

\section{Factors that Influence Higher-Priced Lending}

As described in our assessment of the 2005 data, three basic factors may cause the higher-priced share of lending that is reported under HMDA to change from year to year: (1) changes in the interest rate environment, particularly increases in short-term interest rates; (2) changes in the business practices of lenders, particularly in the products offered and the willingness or ability of lenders to bear credit risk; and (3) changes in the borrowing practices or credit-risk profiles of consumers. Among the borrowing practices at issue are the relative preference for adjustablerate versus fixed-rate loans and for interest rate reduction versus cash-out equity when refinancing; a change in credit-risk profiles would include changes in the distribution of credit scores among borrowers, in the down payments they make, and in their levels of monthly mortgage payment relative to income. Our previous analysis suggested that all three factors were likely responsible for the very large increase from 2004 to 2005 in the reported incidence of higherpriced lending. Quantifying the precise contribution of each of these factors to the change in higher-priced lending proved difficult, however, largely because of a lack of available information within the HMDA data. ${ }^{28}$

\footnotetext{
28. LaCour-Little, "Economic Factors Affecting Home Mortgage
} Disclosure Act Reporting." 
As noted, the incidence of higher-priced lending increased about 2.5 percentage points overall from 2005 to 2006, but, by loan product, changes in the incidence differed considerably over the two years. The most notable changes were increases in the incidence of higher-priced lending for conventional first-lien refinancings on owner-occupied properties, for home-improvement lending, and for lending on non-owner-occupied homes. ${ }^{29}$ The following sections analyze those increases in the incidence of higherpriced lending from 2005 to 2006 in terms of the three factors listed above.

\section{The Changing Interest Rate Situation}

Regulation $\mathrm{C}$ directs lenders to determine whether a loan is higher priced by comparing its APR with the yield on a Treasury security that matches the stated maturity of the loan (refer to notes 5 and 6 ). Thus, the regulation effectively requires lenders to use longerterm interest rates to determine whether to report a loan as higher priced because the stated maturity of most home loans, particularly first-lien loans, typically exceeds twenty years. In contrast, because a mortgage tends to be paid off before its stated maturity, lenders use relatively shorter-term interest rates to help set mortgage rates. ${ }^{30}$ Thus, a mismatch exists between the longer-term yields used to determine higher-priced lending under HMDA and the shorterterm yields used to set mortgage prices.

A yield curve shows the relationship between the yield on a debt instrument and its term to maturity (figure 1, and box "The Yield Curve"). A consequence of the mismatch just described is that a change from one year to the next in the relationship between shortand long-term rates-a change in the slope of the yield curve - can cause a change in the proportion of loans that are reported as higher priced, all other things being equal. Most notably, if shorter-term interest rates increase in a given year relative to longer-term rates, both the number and proportion of loans that exceed the HMDA price-reporting thresholds in that year will be higher than they would have been in the absence of the change in rates even if lender business practices and borrower behavior remain the same.

29. The increase from 2005 to 2006 in the incidence of higherpriced lending for home-purchase loans on non-owner-occupied properties was notable-from 20.3 percent to 28.6 percent. In contrast, the incidence for the purchase of owner-occupied properties increased only slightly over the period, from 24.6 percent to 25.3 percent.

30. Most mortgages are paid off in a relatively short period (typically well before the stated term of the loan is reached) because the individual moves and prepays the loan, or refinances, or defaults.
1. Spread between interest rates on thirty-year and five-year Treasury bonds, 1977-2006

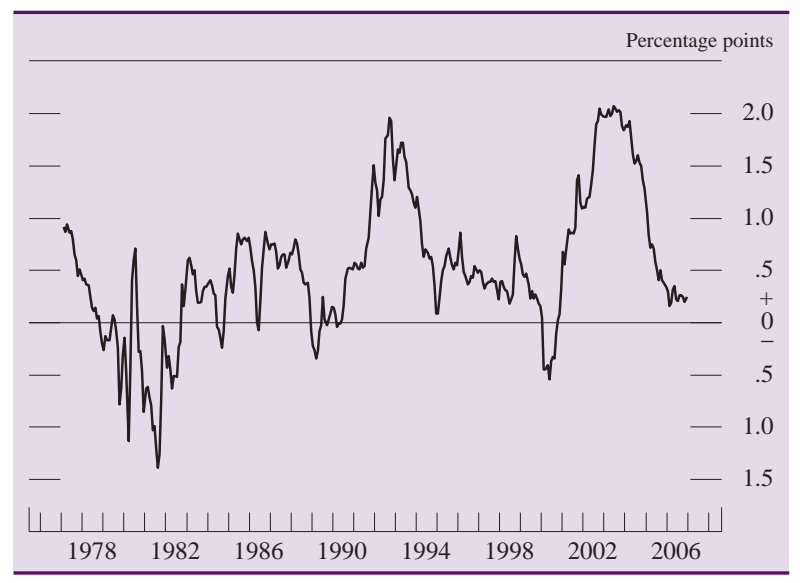

NotE: The data are monthly. After March 2002, the spread is between twenty-year and five-year Treasury bonds.

Source: Federal Financial Institutions Examination Council, "FFIEC Rate Spread Calculator," www.ffiec.gov/ratespread/default.aspx.

Fixed-rate lending and the incidence of higher-priced lending. The changing interest rate environment from 2005 through 2006 likely explains part of the increase from 2005 in the share of reported loans that exceeded the pricing thresholds established by Regulation C. Throughout 2004 and 2005, long-term rates exceeded short-term rates (the yield curve was upward sloping), but the difference narrowed over this period as shorter-term rates increased rather steadily (the slope of the yield curve flattened). The yield curve continued to flatten over much of 2006 as shorter-term rates increased, further narrowing the gap between shortand long-term rates.

Using the methodology similar to that described in our analysis of the 2005 data, we estimate that, if all loans were thirty-year fixed-rate loans, the flattening of the yield curve would have made the 2005-06 rise in the incidence of reported higher-priced lending higher than it would have been in the absence of the yield-curve flattening, as follows (data not shown in tables): The flattening would have increased the rise in higher-priced lending for conventional first-lien home-purchase loans by 1.9 percentage points, and it would have increased the rise for similar loans for refinancings by about 2.3 percentage points. ${ }^{31}$ The actual increase in incidence from 2005 to 2006 was 0.7 percentage point for those home-purchase loans and 5.3 percentage points for those refinancings. Those actual figures imply that if all of the loans reported in HMDA were fixed-rate loans, the change

31. The methodology is described on pp. A147-50 in Avery, Brevoort, and Canner, "Higher-Priced Home Lending and the 2005 HMDA Data." Although the maturities of fixed-rate home loans vary somewhat, the overwhelming majority of them are thirty-year loans. 


\section{The Yield Curve}

The yield curve describes the relationship between interest rates on financial instruments of different maturities (figure A).

The yield curve is typically upward sloping because longer-term investments ordinarily involve greater risk (credit risk, market interest rate risk, and inflation premium), and consequently investors require a higher return to be willing to invest their funds for longer periods. Over the past twenty years, longer-term interest rates (for example, as represented by the annual yield on thirty-year Treasury securities) have almost always exceeded shorterterm interest rates (for example, as represented by the yield on five-year Treasury securities). Figure 1, in the main text, portrays this relationship with the spread, or difference, between the yields on thirty-year and five-year Treasuries. As shown in figure 1 (and as illustrated by the selected dates shown in figure A), the yield curve was especially steep in the 2002-04 period-when short-term rates were quite low by historical standards-but has become much flatter since then and has in fact inverted for short periods.

A. Yield curves on Treasury securities, July 10, 2003 and 2006

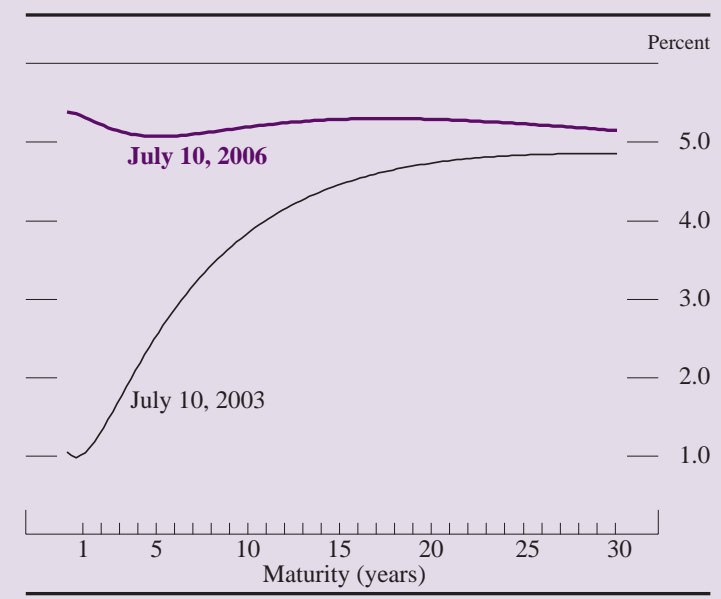

NOTE: Smoothed yield curves estimated from off-the-run Treasury coupon securities. Yields shown are those on notional par Treasury securities with semiannual coupons.

between 2005 and 2006 in the incidence of higherpriced lending for first-lien home-purchase loans would have been a modest decline of about 1.2 percentage points (0.7 less 1.9), as opposed to a modest increase. The increase in the incidence for similar refinancing loans would have been about half of the actual reported increase in higher-priced lending (5.3 less 2.3). Overall, our estimate of the roughly 2 percentage point effect on fixed-rate loans between 2005 and 2006 is similar to our estimate of the corresponding effect between 2004 and 2005.
Additional analysis suggests that another portion of the increase in higher-priced lending arises from the effects of the flattening of the yield curve on adjustable-rate lending. Evidence provided below suggests that the effects of the flattening of the yield curve on adjustable-rate lending might be larger than on the effect on fixed-rate lending.

Adjustable-rate lending and the incidence of higherpriced lending. A steeply upward sloping yield curve suggests that the market expects short-term interest rates to rise. Yet the method of calculation specified under Regulation $\mathrm{Z}$ for deriving the APR for adjustable-rate loans assumes that interest rates will stay the same. Because of this regulatory construct, an upward-sloping yield curve causes the APRs for adjustable-rate loans to be below those for fixed-rate loans of similar term and credit risk. Thus, the flattening of the yield curve can have two effects. First, it can narrow the gap between the longer-term rates used for the HMDA reporting threshold for higher-priced loans and the shorter-term rates used to price loans in the marketplace. Second, a flattening of the yield curve can narrow or even invert the APR gap between adjustable- and fixed-rate loans because, as short-term interest rates increase, the flattening reduces the effect of the comparatively low APR calculations for adjustable-rate loans. The APR gap can be inverted because the expected durations of adjustable- versus fixed-rate loans differ-adjustablerate loans are expected to be outstanding for shorter periods of time. The APR calculations assume that the durations are the same for both adjustable- and fixedrate loans and thus underweight the value to the consumer of low teaser rates offered on many adjustable-rate loans. For these reasons, a likely result of a flattening (or inversion) of the yield curve is an increase in the proportion of adjustable-rate loans that exceed the HMDA price-reporting thresholds.

Figure 2 illustrates these effects of a flattening yield curve. The bottom three lines of the figure represent the differences (spreads) between the APRs of three loan types (the top three lines) and the HMDA reporting threshold. The APRs in the figure are the average rates being offered for prime (best credit-quality) loans for those periods as reported by Freddie Mac. ${ }^{32}$ The three loan types are all thirty-year

32. The rates are from Freddie Mac's Primary Mortgage Market Survey for 2004-06. The Freddie Mac series for five-year adjustable rates did not begin until January 1, 2005. For 2004, we estimated five-year adjustable rates from a statistical model using the one-year adjustable rate and thirty-year fixed rate reported by Freddie Mac and the one- and five-year rates for Treasury securities. 
2. APRs of three selected loan types, and the spread between them and the HMDA price-reporting threshold, 2004-06

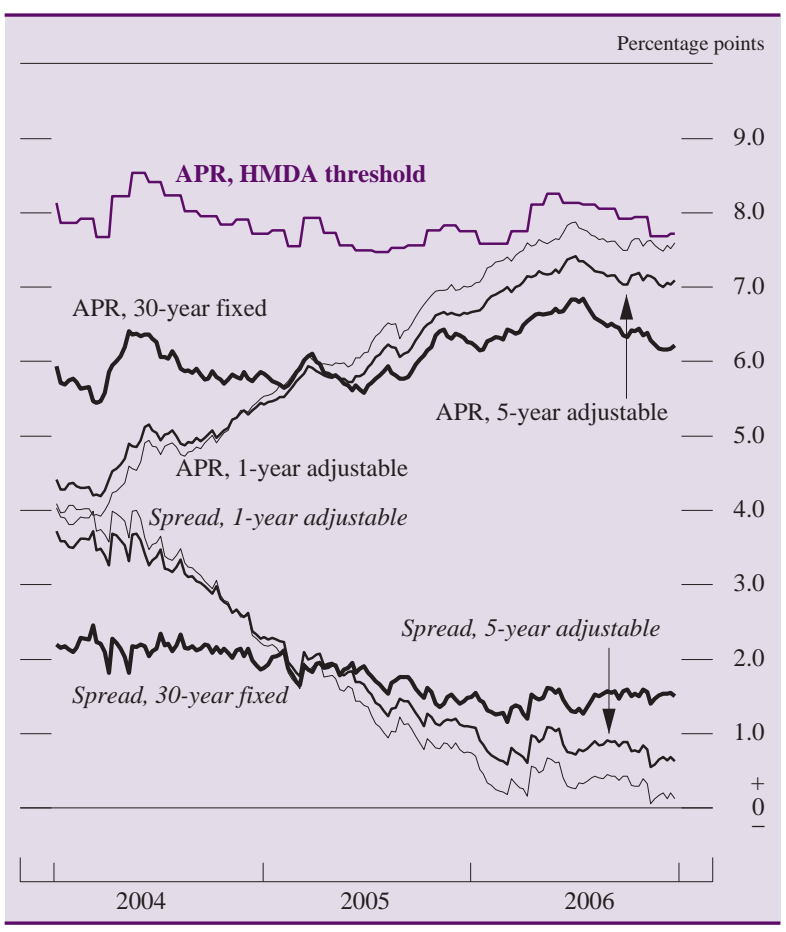

NотE: The data are weekly. Threshold and annual percentage rates (APRs) are for prime, conventional, first-lien mortgages amortized on thirty years. For explanation of threshold, refer to text.

SOURCE: APRs are estimated from Freddie Mac, Primary Mortgage Market Survey.

loans, but for one of them the interest rate is fixed for the life of the loan whereas the rates for the other two reset after one and five years respectively. As thirtyyear first-lien loans, they each have the same HMDA higher-priced reporting threshold-3 percentage points above the yield on the thirty-year Treasury security. The gap between the APR of the typical prime thirty-year fixed-rate loan and the reporting threshold narrowed from 215 basis points at the beginning of 2004 to 144 basis points at the beginning of 2006 and oscillated over the remainder of the year. For prime one-year adjustable-rate loans, the gap narrowed much more, from about 400 basis points at the beginning of 2004 to 52 basis points at the beginning of 2006, then declined further to end the year at only 20 basis points. Thus, at the end of 2006, a one-year adjustable-rate mortgage with a contract rate only 20 basis points above the rate for prime loans as reported by Freddie Mac would have been reported as higher-priced under the HMDA reporting rules.

The differences between the APRs and the reporting threshold decreased for both the fixed-rate and adjustable-rate loans, but the decrease for adjustable- rate loans was much larger. Thus, the gap between the APRs on fixed- and adjustable-rate loans, which was substantial at the beginning of 2004, had been virtually eliminated by early 2005; then the relationship between the two loan types inverted, with APRs on adjustable-rate loans somewhat higher than those on thirty-year fixed-rate loans during most of 2005 and all of 2006. The finding suggests that, as an artifact of regulation, geographic areas may have shown differing incidences of higher-priced lending over the past three years merely because they had differing shares of fixed-rate versus adjustable-rate loans. That is, areas with larger shares of adjustable-rate loans likely had fewer higher-priced loans than areas with larger shares of fixed-rate loans in 2004. This effect should have reversed over the course of 2005 and throughout 2006 as APRs on adjustable-rate loans moved above those on fixed-rate loans.

In the analysis of the 2005 HMDA data, we used information on the mix of adjustable- and fixed-rate loans for each state to derive a rough approximation of the differential effect of the flattening of the yield curve on the proportion of adjustable-rate and fixedrate loans that exceeded the HMDA price-reporting thresholds. ${ }^{33}$ The analysis indicated that states with higher levels of adjustable-rate lending had both relatively low levels of higher-priced lending in 2004 and larger increases in such lending from 2004 to 2005, a pattern that would have been predicted from the narrowing of the APR gap between adjustableand fixed-rate loans.

The data illustrated in figure 2 suggest that the mix of adjustable- and fixed-rate mortgages should be related to changes in the incidence of higher-priced lending between 2005 and 2006, although the differences between these two years are substantially smaller than those between 2004 and 2005. The data support that inference for home-purchase loans, although the effects are very mild. States with the highest proportion of adjustable-rate mortgages showed a greater increase in the incidence of higherpriced home-purchase lending than other states (table 10). The pattern for refinancings was not consistent: The states with the largest share of adjustable-rate mortgages showed about an average increase in the incidence of higher-priced lending for refinancings, which suggests that other factors, such as opportunities to extract equity, played a more dominant role in explaining differences between 2005

33. The mix of adjustable- and fixed-rate loans was derived from data obtained from First American LoanPerformance, www.loanperformance.com 
10. Incidence of higher-priced lending in states grouped by share of originated loans that had an adjustable rate, and the change in incidence, by quintile and type of loan, 2006

\begin{tabular}{|c|c|c|c|c|}
\hline \multirow[b]{2}{*}{ Quintile of states } & \multicolumn{2}{|c|}{ Home purchase } & \multicolumn{2}{|c|}{ Refinance } \\
\hline & 2006 (percent) & $\begin{array}{l}\text { Change, 2005-06 } \\
\text { (percentage points) }\end{array}$ & 2006 (percent) & $\begin{array}{c}\text { Change, 2005-06 } \\
\text { (percentage points) }\end{array}$ \\
\hline Lowest ........ & 19.0 & .8 & 38.3 & 6.7 \\
\hline Second lowest & 20.6 & 1.4 & 33.6 & 5.8 \\
\hline Middle .......... & 23.6 & 1.6 & 31.8 & 5.0 \\
\hline Second highest & 21.6 & -.1 & 29.0 & 5.3 \\
\hline Highest ........ & 26.4 & 4.6 & 31.2 & 5.3 \\
\hline Mемо: California ${ }^{1}$ & 30.2 & 1.4 & 23.3 & 4.6 \\
\hline Total & 24.1 & 1.9 & 30.2 & 5.3 \\
\hline
\end{tabular}

NotE: Spreads are unadjusted. Quintiles based on share of loans originated in 2006 that had an adjustable rate. For definition of higher-priced lending, refer to text.

and 2006 in the incidence of higher-priced lending for refinancings. The role of these factors is discussed below.

Above, we estimated that if all loans were fixed rate, then the effects of the flattening of the yield curve would have been to add approximately 2 percentage points to the reported incidence of higherpriced lending for first-lien loans in the 2006 HMDA data. However, adjustable-rate first-lien mortgages are not as homogenous as fixed-rate loans; substantial proportions of the adjustable-rate loans have variously, for example, one-year, five-year, and sevenyear introductory (fixed-rate) periods. We estimate that, if all loans had adjustable rates, the yield-curve effect would have added on the order of 4 or 5 percentage points-depending on the mix of adjustment terms - to the reported incidence of higher-priced lending. Thus, depending on the overall mix of fixedand adjustable-rate loans and the mix of types among loans with adjustable rates, the effect of the yield curve flattening on the incidence of higher-priced loans would have been to increase the incidence by an amount somewhere between that for the all-fixed-rate assumption and that for the all-adjustable-rate assumption - that is, on the order of 3 or 4 percentage points. That estimate implies that had there been no yield-curve changes, the incidence of higher-priced home-purchase loans would have fallen and the incidence for refinancings would have shown only a modest increase.

\section{Real Effects on the Incidence of Higher-Priced Lending}

To the extent that changes in the incidence of higherpriced lending are caused by yield-curve effects, they are not a result of changes in the business practices of
1. California is shown separately because it accounts for a large number of loans and has a high incidence of adjustable-rate lending.

lenders nor in the credit-risk profiles of consumers. ${ }^{34}$ The importance of the latter two factors in explaining changes in the "real" incidence of higher-priced lending is difficult to gauge.

The housing market, and economic conditions more generally, were favorable in the 2004-05 period. Sales of both new and existing homes in 2005 eclipsed the historic highs reached in 2004. Housing market conditions began moderating in 2006: For the year, home prices rose more slowly in many areas and declined in some others. Nationally, the median price for existing homes increased throughout 2005, reached a high in July 2006, and then declined over the remainder of the year. Nonetheless, the overall median price of existing homes was higher at year-end 2006 than at year-end 2005. In addition, a steady climb in short-term interest rates pushed up monthly payments for some existing borrowers with adjustablerate loans and for those taking out new such loans. ${ }^{35}$ Thus, nationally, housing affordability fell from 2005 to 2006 , which suggests that more borrowers may have had to stretch financially to purchase or refinance the mortgages on their homes. ${ }^{36}$

Moreover, higher interest rates altered the mix of individuals seeking to refinance their loans. Historically, individuals have refinanced their loans for one

34. As discussed in the preceding section, the yield-curve effects are an artifact of the Regulation $\mathrm{C}$ definition of a higher-priced loan and the specification in Regulation $\mathrm{Z}$ of the method of calculating APRs (particularly for adjustable-rate loans).

35. Because many adjustable-rate loans have an initial period at a fixed rate (often two or three years from loan origination), some borrowers with such loans do not experience an immediate change in their payments if interest rates increase. For new borrowers, an increase in short-term rates generally results in a corresponding increase in the initial rate on the loan.

36. Information on the sales, prices, and affordability of homes is in U.S. Department of Housing and Urban Affairs, U.S. Housing Market Conditions, www.huduser.org/periodicals/ushmc.html. 
or both of the following reasons: to lower the interest rate on the debt or to extract some of the accumulated equity in their home. The latter purpose (sometimes referred to as cash-out refinancing) is accomplished by borrowing more than is needed to cover the closing costs of the new loan plus the existing balance of the old loan. Increases in interest rates during 2005 and the first part of 2006 reduced the opportunities for individuals to benefit from rate-reduction refinancings, so the proportion of borrowers in the refinance market who were seeking equity extraction likely rose in $2006 .{ }^{37}$

The less-favorable conditions in the housing market and in the interest rate environment in 2006 relative to 2005 undoubtedly account for much of the decline in the number of mortgage originations reported in the HMDA data for 2006, particularly with regard to the sharp decline in refinancings (about 15 percent). It also likely explains the increase from 2005, apart from the effects of the yield-curve flattening, in the proportion of borrowers who obtained higher-priced loans in the market for refinancings. The rise in the incidence of higher-priced lending in the refinance market (particularly when compared with the home-purchase market) seems to have come primarily from the aforementioned rise in the proportion of borrowers in the refinance market who were seeking to raise cash-and equity extraction is a major reason for borrowers in the higher-priced segment market to refinance. ${ }^{38}$ In short, the increase in the incidence of higher-priced lending in the refinance market, at least relative to the home-purchase market, appears to have been driven mainly by a decrease in the number of prime borrowers in this market rather than by an increase in borrowers with weaker credit profiles.

Industry data provide additional support for the view that real credit quality declined from 2005 to 2006, albeit modestly. However, most of the change

37. Data published by Freddie Mac indicate that the share of refinancings involving a cash-out rose steadily over the course of 2005 and through the third quarter of 2006 (www.freddiemac.com/news/ finance/refi_archives.htm).

38. This conclusion follows from the belief that the credit profiles of those extracting equity are, in general, worse than those that refinance purely to benefit from interest rate reductions. Empirical evidence on delinquency rates for refinancings involving equity extraction is generally consistent with this belief. However, in areas that have experienced exceptional increases in home values, the expected credit profiles of those extracting equity may not be worse than others because such borrowers may benefit from relatively low loan-to-value ratios. That condition may explain, for example, the relatively low incidence of higher-priced lending for refinancings in California (table 10), a state with a high incidence of higher-priced lending for home purchases. California was among the states with the largest increases in home values in recent years. in credit quality seems to have taken place in the near-prime, or "alt-A," portion of the market. For example, estimates show that from 2005 to 2006, the subprime share of all mortgage originations held steady at about 20 percent, whereas, over the same period, the alt-A portion of the market rose from 12.2 percent to 13.4 percent. $^{39}$

\section{DIFFERENCES IN LENDING OUTCOMES BY RACE, ETHNICITY, AND SEX OF BORROWER}

One purpose of the HMDA data is to allow comparisons of lending outcomes across borrowers grouped by their race, ethnicity, or sex. Three types of outcomes often assessed are the incidence of higherpriced lending (that is, the percentage of loans that were higher priced), the price spreads on the higherpriced loans (that is, the amount by which the APRs on those loans were above the HMDA reporting threshold), and denial rates. Analysis of the 2004 and 2005 HMDA data found that differences across groups in mean spreads paid by those with higherpriced loans were generally small. However, the analysis revealed substantial differences across racial and ethnic lines in the incidence of higher-priced lending and in denial rates; further, it showed that such differences could not be fully explained by factors included in the HMDA data.

In examining 2006 lending outcomes by the race, ethnicity, and sex of borrowers, the present analysis focuses on home-purchase and refinancing loans that are conventional first liens on owner-occupied, oneto four-family, site-built homes. Those types of homepurchase and refinancing loans together represent, by far, the largest number of reported mortgages in the HMDA data: For 2006, the home-purchase category comprised 6.2 million applications and 3.9 million loans; the refinancing category comprised 10.4 million applications and 4.3 million loans (table 4).

The HMDA data include only some of the many factors directly considered by lenders in the process of credit underwriting and pricing. Among the borrower-related items in the HMDA data that are likely related to the loan underwriting and pricing process are property location, income relied on in underwriting, loan amount, time of year when the loan was made, and presence of a co-applicant. Because of the focus here on specific loan product categories, the analysis already accounts in broad

39. Estimate derived from Inside Mortgage Finance, The 2007 Mortgage Market Statistical Annual. 
terms for loan type and purpose, type of property securing the loan, lien status, and owner-occupancy status.

In comparing lending outcomes across racial and ethnic groups, one can match for the sex of the applicant and co-applicant. Accounting for sex in the analysis is intended to better distinguish pricing issues related purely to the race or ethnicity of the borrower from those that could be related to sex. In assessing lending outcomes by sex, one can match for race and ethnicity, once again to make comparisons as precise as possible.

The pricing analysis here focuses on both the incidence of higher-priced lending and the mean APR spreads paid by borrowers with higher-priced loans. Comparisons of these outcomes are made across eleven groups-nine racial or ethnic groups and the two sexes. Comparisons of average outcomes for each group are made both before and after modifying the results for (1) differences in the borrower-related factors cited earlier and (2) differences in the borrowerrelated factors plus the specific lending institution used by the borrower. ${ }^{40}$ The method of controlling for these factors is to gather borrower data into cells or groupings; in each cell, borrowers are similar along the dimensions considered. The methodology used here is the same as that described in the previously cited articles in the Federal Reserve Bulletin assessing the 2004 and 2005 HMDA data.

Comparisons for lending outcomes across groups are of three types: gross ("unmodified"), modified to account for borrower-related factors ("borrower modified"), and modified for borrower-related factors plus lender ("borrower-plus-lender modified"). For purposes of presentation, the borrower-modified and borrower-plus-lender-modified outcomes shown in the tables are normalized so that, for the base comparison group (non-Hispanic whites in the case of comparison by race and ethnicity, and males in the case of comparison by sex), the mean at each modification level is the same as the gross mean. Consequently, the borrower-modified and borrower-pluslender-modified outcomes for any other group represent the expected average outcome if the members of that group had the same distribution of control factors as that of the base comparison group.

40. To recall, the borrower-related factors are income, loan amount, metropolitan statistical area (MSA) of the property, presence of a co-applicant, and (in the comparisons by race and ethnicity) sex. Excluded from the pricing analysis are applicants residing outside the fifty states and the District of Columbia and applications deemed to be business related.

\section{Incidence of Higher-Priced Lending by Race and Ethnicity}

The 2006 HMDA data, like the 2004 and 2005 data, indicate that black and Hispanic borrowers are more likely, and Asians borrowers less likely, to obtain loans with prices above the HMDA pricing reporting thresholds than are non-Hispanic white borrowers. These relationships are found for both home-purchase loans and refinancings (table 11). ${ }^{41}$ Gross differences in the incidence of higher-priced lending between non-Hispanic whites, on the one hand, and blacks or Hispanic whites, on the other, are large, but borrowerplus-lender-modified differences are substantially reduced. Most of the reduction in the difference in the incidence across groups comes from adding the control for lender to the control for borrower-related factors, an indication that the pricing differences in a given lender's underwriting are typically smaller than the differences among loans across lenders.

For home-purchase loans in 2006, the gross mean incidence of higher-priced lending was 53.7 percent for blacks and 17.7 percent for non-Hispanic whites, a difference of 36.0 percentage points (table 11, top panel). Borrower-related factors included in the HMDA data accounted for about one-sixth of the unmodified difference. Controlling further for lender reduces the remaining gap to 12.6 percentage points. In comparison, in 2005, the unmodified mean incidence of higher-priced lending for such loans was 54.7 percent for blacks and 17.2 percent for nonHispanic whites, a difference of 37.5 percentage points. For 2005, borrower-related factors accounted for about one-fifth of the unmodified difference, and controlling further for borrower and lender reduced the remaining gap to 10 percentage points, a somewhat smaller "unexplained" difference than that found in the 2006 data.

For refinancings in 2006, the difference between blacks and non-Hispanic whites in the unmodified mean incidence of higher-priced lending was 27.1 percentage points, and the borrower-plus-lender-related difference was 7.3 percentage points; once again, most of the reduction in differences came from the addition of the control for lender (table 11, bottom

41. Applicants are placed under only one category for race and ethnicity, generally according to the race and ethnicity of the person listed first on the application. However, under race, the application is designated as joint if one applicant reported the single designation of white and the other reported one or more minority races. If the application is not joint but more than one race is reported, the following designations are made: If at least two minority races are reported, the application is designated as two or more minority races; if the first person listed on an application reports two races, and one is white, the application is categorized under the minority race. 
11. Incidence of higher-priced lending, unmodified and modified for borrower- and lender-related factors, for conventional first liens on owner-occupied one- to four-family site-built homes, by type of loan and by race, ethnicity, and sex of borrower, 2005 and 2006

Percent except as noted

\begin{tabular}{|c|c|c|c|c|c|c|c|c|}
\hline \multirow{3}{*}{ Race, ethnicity, and sex ${ }^{1}$} & \multicolumn{4}{|c|}{2005} & \multicolumn{4}{|c|}{2006} \\
\hline & \multirow{2}{*}{$\begin{array}{l}\text { Number of } \\
\text { loans }\end{array}$} & \multirow{2}{*}{$\begin{array}{l}\text { Unmodified } \\
\text { incidence }\end{array}$} & \multicolumn{2}{|c|}{$\begin{array}{l}\text { Modified incidence, by } \\
\text { modification factor }\end{array}$} & \multirow{2}{*}{$\begin{array}{l}\text { Number of } \\
\text { loans }\end{array}$} & \multirow{2}{*}{$\begin{array}{l}\text { Unmodified } \\
\text { incidence }\end{array}$} & \multicolumn{2}{|c|}{$\begin{array}{l}\text { Modified incidence, by } \\
\text { modification factor }\end{array}$} \\
\hline & & & $\begin{array}{l}\text { Borrower- } \\
\text { related }\end{array}$ & $\begin{array}{l}\text { Borrower- } \\
\text { related plus } \\
\text { lender }\end{array}$ & & & $\begin{array}{l}\text { Borrower- } \\
\text { related }\end{array}$ & $\begin{array}{l}\text { Borrower- } \\
\text { related plus } \\
\text { lender }\end{array}$ \\
\hline & \multicolumn{8}{|c|}{ Home purchase } \\
\hline 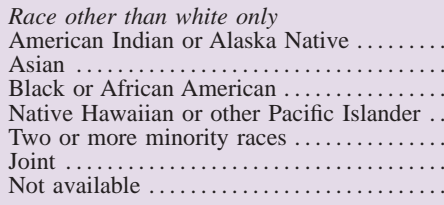 & $\begin{array}{r}27,766 \\
237,383 \\
312,451 \\
23,450 \\
2,112 \\
51,881 \\
431,159\end{array}$ & $\begin{array}{l}35.3 \\
16.6 \\
54.7 \\
34.8 \\
30.4 \\
18.2 \\
32.4\end{array}$ & $\begin{array}{l}29.5 \\
15.8 \\
47.0 \\
30.4 \\
28.7 \\
23.0 \\
33.6\end{array}$ & $\begin{array}{l}21.8 \\
16.6 \\
27.2 \\
21.0 \\
20.8 \\
19.0 \\
21.6\end{array}$ & $\begin{array}{r}21,615 \\
187,187 \\
318,650 \\
18,773 \\
2,112 \\
44,666 \\
377,985\end{array}$ & $\begin{array}{l}34.2 \\
16.8 \\
53.7 \\
34.0 \\
27.6 \\
17.5 \\
29.2\end{array}$ & $\begin{array}{l}30.5 \\
15.3 \\
47.6 \\
29.2 \\
28.6 \\
23.8 \\
31.8\end{array}$ & $\begin{array}{l}24.5 \\
16.8 \\
30.3 \\
22.9 \\
20.7 \\
19.8 \\
23.3\end{array}$ \\
\hline $\begin{array}{l}\text { White, by ethnicity } \\
\text { Hispanic white } \ldots \ldots \ldots \ldots \ldots \ldots \ldots \ldots \ldots \ldots \ldots \\
\text { Non-Hispanic white } \ldots \ldots \ldots \ldots \ldots \ldots \ldots\end{array}$ & $\begin{array}{r}464,634 \\
2,789,265\end{array}$ & $\begin{array}{l}46.1 \\
17.2\end{array}$ & $\begin{array}{l}34.2 \\
17.2\end{array}$ & $\begin{array}{l}21.9 \\
17.2\end{array}$ & $\begin{array}{r}464,291 \\
2,406,570\end{array}$ & $\begin{array}{l}46.6 \\
17.7\end{array}$ & $\begin{array}{l}35.1 \\
17.7\end{array}$ & $\begin{array}{l}24.0 \\
17.7\end{array}$ \\
\hline 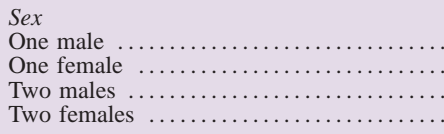 & $\begin{array}{r}1,392,947 \\
1,021,006 \\
44,278 \\
36,140\end{array}$ & $\begin{array}{l}31.7 \\
30.8 \\
23.1 \\
24.7\end{array}$ & $\begin{array}{l}31.7 \\
29.8 \\
23.1 \\
22.4\end{array}$ & $\begin{array}{l}31.7 \\
30.8 \\
23.1 \\
23.9\end{array}$ & $\begin{array}{r}1,255,567 \\
925,029 \\
36,405 \\
31,062\end{array}$ & $\begin{array}{l}32.3 \\
30.9 \\
23.9 \\
26.2\end{array}$ & $\begin{array}{l}32.3 \\
30.2 \\
23.9 \\
22.5\end{array}$ & $\begin{array}{l}32.3 \\
31.2 \\
23.9 \\
23.4\end{array}$ \\
\hline Two females $\ldots \ldots \ldots \ldots \ldots \ldots \ldots \ldots \ldots$ & \multicolumn{8}{|c|}{ Refinance } \\
\hline 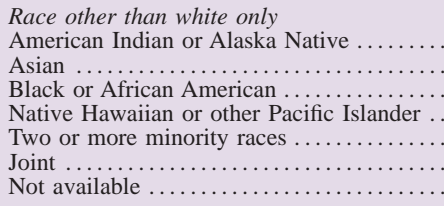 & $\begin{array}{r}37,213 \\
165,011 \\
441,299 \\
31,453 \\
3,650 \\
61,200 \\
752,573\end{array}$ & $\begin{array}{l}28.9 \\
15.2 \\
49.3 \\
28.4 \\
28.6 \\
19.3 \\
32.2\end{array}$ & $\begin{array}{l}32.1 \\
18.9 \\
45.0 \\
32.2 \\
29.5 \\
26.2 \\
38.0\end{array}$ & $\begin{array}{l}24.1 \\
21.1 \\
27.2 \\
24.3 \\
24.2 \\
22.4 \\
24.5\end{array}$ & $\begin{array}{r}27,748 \\
127,873 \\
397,452 \\
24,078 \\
2,913 \\
41,875 \\
570,431\end{array}$ & $\begin{array}{l}32.8 \\
19.6 \\
52.8 \\
33.6 \\
28.0 \\
26.2 \\
38.2\end{array}$ & $\begin{array}{l}36.1 \\
23.7 \\
50.0 \\
37.5 \\
28.9 \\
33.3 \\
43.7\end{array}$ & $\begin{array}{l}29.5 \\
25.3 \\
33.0 \\
30.0 \\
30.8 \\
26.9 \\
30.6\end{array}$ \\
\hline $\begin{array}{l}\text { White, by ethnicity } \\
\text { Hispanic white } \ldots \ldots \ldots \ldots \ldots \ldots \ldots \ldots \ldots \\
\text { Non-Hispanic white } \ldots \ldots \ldots \ldots \ldots \ldots\end{array}$ & $\begin{array}{r}478,381 \\
3,496,425\end{array}$ & $\begin{array}{l}33.8 \\
21.0\end{array}$ & $\begin{array}{l}31.5 \\
21.0\end{array}$ & $\begin{array}{l}23.6 \\
21.0\end{array}$ & $\begin{array}{r}437,163 \\
2,596,873\end{array}$ & $\begin{array}{l}37.7 \\
25.7\end{array}$ & $\begin{array}{l}37.0 \\
25.7\end{array}$ & $\begin{array}{l}29.7 \\
25.7\end{array}$ \\
\hline 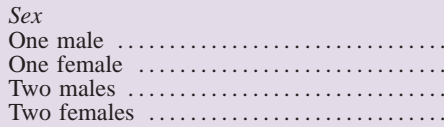 & $\begin{array}{r}1,424,721 \\
1,229,138 \\
37,442 \\
41,572\end{array}$ & $\begin{array}{l}30.3 \\
31.1 \\
21.2 \\
27.0\end{array}$ & $\begin{array}{l}30.3 \\
30.0 \\
21.2 \\
23.5\end{array}$ & $\begin{array}{l}30.3 \\
30.4 \\
21.2 \\
22.5\end{array}$ & $\begin{array}{r}1,197,165 \\
1,033,700 \\
27,336 \\
31,179\end{array}$ & $\begin{array}{l}34.6 \\
35.3 \\
26.6 \\
34.1\end{array}$ & $\begin{array}{l}34.6 \\
34.3 \\
26.6 \\
29.9\end{array}$ & $\begin{array}{l}34.6 \\
34.5 \\
26.6 \\
26.6\end{array}$ \\
\hline
\end{tabular}

Note: Excludes transition-period loans (those for which the application was submitted before 2004). For definition of higher-priced lending and explanations of spread adjustment and of modification factors, refer to text.

1. Categories for race and ethnicity reflect the revised standards established in 1997 by the Office of Management and Budget. For method of allocation

panel). In comparison, in 2005, the unmodified difference in incidence between blacks and non-Hispanic whites was 28.3 percentage points, and the borrowerplus-lender-related difference was 6.2 percentage points. As in 2006, most of the reduction in 2005 came from the addition of the control for lender. Relationships are similar for comparisons made between Hispanic whites and non-Hispanic whites, but the unmodified difference in incidence between these two groups (12 percentage points in 2006) is notably smaller than that between blacks and non-Hispanic whites, and much of the difference is attributable to borrower-related factors and lender. into racial and ethnic categories and definitions of categories, refer to text note 41. Loans taken out jointly by a male and female are not tabulated here because they would not be directly comparable with loans taken out by one borrower or by two borrowers of the same sex.

The situation for Asians differs greatly from that for blacks or Hispanic whites: Compared with nonHispanic whites, Asians had a lower unmodified mean incidence of higher-priced lending in 2006 for home-purchase and refinance loans. Borrower-related factors plus lender do not alter the gap in incidence but narrow it for refinancings.

\section{Rate Spreads by Race and Ethnicity}

The 2006 data indicate that among borrowers with higher-priced loans, the unmodified mean spread of prices paid by black borrowers are moderately higher, 
12. Mean APR spreads, unmodified and modified for borrower- and lender-related factors, for higher-priced conventional first liens on owner-occupied one- to four-family site-built homes, by type of loan and by race, ethnicity, and sex of borrower, 2005 and 2006

Percentage points except as noted

\begin{tabular}{|c|c|c|c|c|c|c|c|c|}
\hline \multirow{3}{*}{ Race, ethnicity, and sex } & \multicolumn{4}{|c|}{2005} & \multicolumn{4}{|c|}{2006} \\
\hline & \multirow{2}{*}{$\begin{array}{c}\text { Number of } \\
\text { higher-priced } \\
\text { loans }\end{array}$} & \multirow{2}{*}{$\begin{array}{l}\text { Unmodified } \\
\text { mean spread }\end{array}$} & \multicolumn{2}{|c|}{$\begin{array}{l}\text { Modified mean spread, by } \\
\text { modification factor }\end{array}$} & \multirow{2}{*}{$\begin{array}{c}\text { Number of } \\
\text { higher-priced } \\
\text { loans }\end{array}$} & \multirow{2}{*}{$\begin{array}{l}\text { Unmodified } \\
\text { mean spread }\end{array}$} & \multicolumn{2}{|c|}{$\begin{array}{l}\text { Modified mean spread, by } \\
\text { modification factor }\end{array}$} \\
\hline & & & $\begin{array}{l}\text { Borrower- } \\
\text { related }\end{array}$ & $\begin{array}{l}\text { Borrower- } \\
\text { related plus } \\
\text { lender }\end{array}$ & & & $\begin{array}{l}\text { Borrower- } \\
\text { related }\end{array}$ & $\begin{array}{l}\text { Borrower- } \\
\text { related plus } \\
\text { lender }\end{array}$ \\
\hline & \multicolumn{8}{|c|}{ Home purchase } \\
\hline 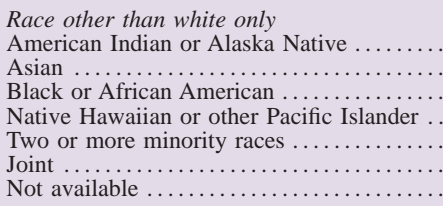 & $\begin{array}{r}9,799 \\
39,471 \\
171,009 \\
8,162 \\
641 \\
9,468 \\
139,740\end{array}$ & $\begin{array}{l}4.6 \\
4.6 \\
5.0 \\
4.6 \\
4.8 \\
4.6 \\
4.9\end{array}$ & $\begin{array}{l}4.8 \\
4.7 \\
4.9 \\
4.8 \\
4.9 \\
4.8 \\
4.9\end{array}$ & $\begin{array}{l}4.8 \\
4.7 \\
4.9 \\
4.8 \\
4.8 \\
4.8 \\
4.8\end{array}$ & $\begin{array}{r}7,388 \\
31,395 \\
171,238 \\
6,376 \\
583 \\
7,802 \\
110,527\end{array}$ & $\begin{array}{l}5.2 \\
5.0 \\
5.7 \\
5.2 \\
5.4 \\
5.3 \\
5.5\end{array}$ & $\begin{array}{l}5.2 \\
5.1 \\
5.6 \\
5.2 \\
5.4 \\
5.3 \\
5.5\end{array}$ & $\begin{array}{l}5.2 \\
5.1 \\
5.3 \\
5.1 \\
5.3 \\
5.2 \\
5.3\end{array}$ \\
\hline $\begin{array}{l}\text { White, by ethnicity } \ldots \ldots \ldots \ldots \ldots \ldots \ldots \ldots \ldots \\
\text { Hispanic white } \ldots \ldots \ldots \ldots \ldots \ldots \ldots \ldots \ldots \ldots \\
\text { Non-Hispanic white } \ldots \ldots \ldots \ldots \ldots \ldots \ldots\end{array}$ & $\begin{array}{l}214,415 \\
479,338\end{array}$ & $\begin{array}{l}4.6 \\
4.7\end{array}$ & $\begin{array}{l}4.7 \\
4.7\end{array}$ & $\begin{array}{l}4.8 \\
4.7\end{array}$ & $\begin{array}{l}216,422 \\
426,138\end{array}$ & $\begin{array}{l}5.3 \\
5.1\end{array}$ & $\begin{array}{l}5.2 \\
5.1\end{array}$ & $\begin{array}{l}5.2 \\
5.1\end{array}$ \\
\hline 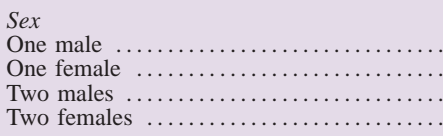 & $\begin{array}{r}441,919 \\
313,959 \\
10,213 \\
8,943\end{array}$ & $\begin{array}{l}4.8 \\
4.8 \\
4.5 \\
4.7\end{array}$ & $\begin{array}{l}4.8 \\
4.8 \\
4.5 \\
4.6\end{array}$ & $\begin{array}{l}4.8 \\
4.8 \\
4.5 \\
4.5\end{array}$ & $\begin{array}{r}405,414 \\
285,937 \\
8,716 \\
8,142\end{array}$ & $\begin{array}{l}5.3 \\
5.3 \\
5.2 \\
5.4\end{array}$ & $\begin{array}{l}5.3 \\
5.3 \\
5.2 \\
5.3\end{array}$ & $\begin{array}{l}5.3 \\
5.3 \\
5.2 \\
5.2\end{array}$ \\
\hline Two females $\ldots \ldots \ldots \ldots \ldots \ldots \ldots \ldots \ldots \ldots \ldots \ldots$ & \multicolumn{8}{|c|}{ Refinance } \\
\hline 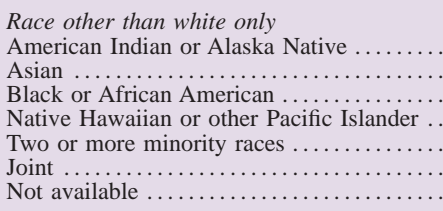 & $\begin{array}{r}10,770 \\
25,119 \\
217,351 \\
8,945 \\
1043 \\
11,815 \\
242,666\end{array}$ & $\begin{array}{l}4.8 \\
4.7 \\
5.0 \\
4.8 \\
4.9 \\
4.7 \\
5.0\end{array}$ & $\begin{array}{l}4.8 \\
4.8 \\
5.0 \\
4.8 \\
4.9 \\
4.8 \\
5.0\end{array}$ & $\begin{array}{l}4.8 \\
4.8 \\
4.9 \\
4.8 \\
4.8 \\
4.8 \\
4.8\end{array}$ & $\begin{array}{r}9,096 \\
25,096 \\
209,910 \\
8,102 \\
815 \\
10,958 \\
217,915\end{array}$ & $\begin{array}{l}5.1 \\
4.9 \\
5.4 \\
5.1 \\
5.2 \\
5.0 \\
5.3\end{array}$ & $\begin{array}{l}5.1 \\
5.0 \\
5.3 \\
5.1 \\
5.3 \\
5.1 \\
5.3\end{array}$ & $\begin{array}{l}5.1 \\
5.1 \\
5.2 \\
5.1 \\
5.2 \\
5.1 \\
5.1\end{array}$ \\
\hline $\begin{array}{l}\text { White, by ethnicity } \\
\text { Hispanic white ...... } \\
\text { Non-Hispanic white }\end{array}$ & $\begin{array}{l}161,713 \\
733,290\end{array}$ & $\begin{array}{l}4.8 \\
4.8\end{array}$ & $\begin{array}{l}4.8 \\
4.8\end{array}$ & $\begin{array}{l}4.8 \\
4.8\end{array}$ & $\begin{array}{l}164,748 \\
668,337\end{array}$ & $\begin{array}{l}5.1 \\
5.1\end{array}$ & $\begin{array}{l}5.1 \\
5.1\end{array}$ & $\begin{array}{l}5.1 \\
5.1\end{array}$ \\
\hline 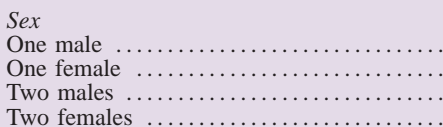 & $\begin{array}{r}432,386 \\
382,071 \\
7,937 \\
11,208\end{array}$ & $\begin{array}{l}4.9 \\
4.9 \\
4.8 \\
4.8\end{array}$ & $\begin{array}{l}4.9 \\
4.9 \\
4.8 \\
4.8\end{array}$ & $\begin{array}{l}4.9 \\
4.9 \\
4.8 \\
4.8\end{array}$ & $\begin{array}{r}414,387 \\
365,368 \\
7,276 \\
10,646\end{array}$ & $\begin{array}{l}5.2 \\
5.2 \\
5.0 \\
5.1\end{array}$ & $\begin{array}{l}5.2 \\
5.2 \\
5.0 \\
5.1\end{array}$ & $\begin{array}{l}5.2 \\
5.2 \\
5.0 \\
5.0\end{array}$ \\
\hline
\end{tabular}

NotE: Spread-unadjusted APR is the difference between the APR on the loan and the yield on a comparable-maturity Treasury security. Spread-adjusted APR is the difference between the APR on the loan and the estimated APR

and those paid by Hispanic white borrowers are slightly higher, than those paid by non-Hispanic white borrowers (table 12). The spread of prices paid by Asian borrowers with higher-priced loans was about the same, on average, as that by non-Hispanic whites with higher-priced loans. These relationships are generally consistent for both types of loan and are little influenced by borrower-related factors or the specific lender used by the borrowers.

\section{Pricing Differences by Sex}

The HMDA data for 2006, like those for previous years, reveal little difference in pricing outcomes by sex. For example, sole female borrowers generally reported by Freddie Mac for a thirty-year fixed-rate loan in their Primary Mortgage Market Survey. Excludes transition-period loans (those for which the application was submitted before 2004). Refer also to note 1 , table 11 .

have a slightly lower incidence of higher-priced lending than sole male borrowers for home-purchase loans both before and after accounting for borrowerrelated factors plus lender (table 11). Similarly, the average spreads on prices paid by females with higher-priced loans are virtually the same as those paid by males after accounting for the presence or absence of a co-borrower (table 12).

\section{Denial Rates by Race, Ethnicity, and Sex}

Analyses of the HMDA data from earlier years has consistently found that denial rates vary by applicant race and ethnicity. For the 2006 home-purchase and refinance loans examined here on an unmodified 
13. Denial rates on applications, unmodified and modified for borrower- and lender-related factors, for conventional first liens on owner-occupied, one- to four-family, site-built homes, by type of loan and by race, ethnicity, and sex of applicant, 2006

Percent except as noted

\begin{tabular}{|c|c|c|c|c|c|c|c|c|}
\hline \multirow{3}{*}{ Race, ethnicity, and sex } & \multicolumn{3}{|c|}{ Home purchase } & \multicolumn{3}{|c|}{ Refinance } & & \\
\hline & \multirow{2}{*}{$\begin{array}{c}\text { Number of } \\
\text { applications } \\
\text { acted upon } \\
\text { by lender }\end{array}$} & \multirow{2}{*}{$\begin{array}{l}\text { Unmodified } \\
\text { denial rate }\end{array}$} & \multicolumn{2}{|c|}{$\begin{array}{l}\text { Modified denial rate, by } \\
\text { modification factor }\end{array}$} & \multirow{2}{*}{$\begin{array}{l}\text { Number of } \\
\text { applications } \\
\text { acted upon } \\
\text { by lender }\end{array}$} & \multirow{2}{*}{$\begin{array}{l}\text { Unmodified } \\
\text { denial rate }\end{array}$} & \multicolumn{2}{|c|}{$\begin{array}{l}\text { Modified denial rate, by } \\
\text { modification factor }\end{array}$} \\
\hline & & & $\begin{array}{l}\text { Borrower- } \\
\text { related }\end{array}$ & $\begin{array}{l}\text { Borrower- } \\
\text { related plus } \\
\text { lender }\end{array}$ & & & $\begin{array}{l}\text { Borrower- } \\
\text { related }\end{array}$ & $\begin{array}{l}\text { Borrower- } \\
\text { related plus } \\
\text { lender }\end{array}$ \\
\hline \multicolumn{9}{|l|}{ Race other than white only } \\
\hline American Indian or Alaska Native .... & 34,646 & 25.9 & 22.2 & 18.2 & 63,757 & 44.7 & 44.8 & 37.7 \\
\hline 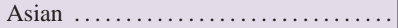 & 264,397 & 17.0 & 14.5 & 14.8 & 215,172 & 27.7 & 33.2 & 34.6 \\
\hline Black or African American .... & 553,168 & 31.6 & 27.7 & 21.5 & 883,842 & 44.9 & 46.2 & 38.7 \\
\hline $\begin{array}{l}\text { Native Hawaiian or } \\
\text { other Pacific Islander } \ldots \ldots \text {. }\end{array}$ & 29,104 & 23.4 & 20.3 & 17.4 & 47,437 & 36.4 & 41.8 & 37.5 \\
\hline Two or more minority races & $\begin{array}{r}27,139 \\
3,139\end{array}$ & 20.2 & 18.0 & 17.2 & 5,878 & 40.5 & 42.9 & 37.3 \\
\hline Joint .................. & 57,781 & 13.6 & 17.0 & 14.9 & 74,030 & 34.0 & 40.3 & 34.4 \\
\hline Not available ......... & 611,069 & 24.2 & 23.7 & 18.1 & $1,448,614$ & 48.0 & 49.6 & 38.3 \\
\hline \multicolumn{9}{|l|}{ White, by ethnicity . } \\
\hline Hispanic white .... & 719,166 & 25.4 & 20.3 & 17.5 & 801,813 & 33.5 & 36.6 & 35.8 \\
\hline Non-Hispanic white & $3,063,436$ & 13.1 & 13.1 & 13.1 & $4,343,279$ & 30.6 & 30.6 & 30.6 \\
\hline \multicolumn{9}{|l|}{ Sex } \\
\hline One male . & $1,833,621$ & 21.7 & 21.7 & 21.7 & $2,324,086$ & 37.6 & 37.6 & 37.6 \\
\hline One female $\ldots$ & $1,334,498$ & 21.0 & 20.5 & 20.9 & $1,926,089$ & 36.1 & 35.0 & 35.9 \\
\hline Two males ...... & 50,505 & 19.2 & 19.2 & 19.2 & 50,870 & 36.5 & 36.5 & 36.5 \\
\hline Two females $\ldots \ldots \ldots \ldots \ldots \ldots$ & 43,322 & 19.5 & 17.4 & 17.7 & 60,185 & 39.5 & 36.8 & 36.1 \\
\hline
\end{tabular}

NoTE: Includes transition-period applications (those submitted before 2004). For explanation of modification factors, refer to text. Refer also to note 1, table 11.

basis, American Indians, blacks, and Hispanic whites had higher denial rates than non-Hispanic whites; blacks had the highest rates; and Hispanic whites had rates between those for blacks and those for nonHispanic whites. The pattern was less consistent for Asians, who had higher denial rates than nonHispanic whites for home purchase but lower rates for refinancings (table 13).

For home-purchase lending, controlling for borrower-related factors in the HMDA data reduces the differences in denial rates among racial and ethnic groups. Accounting for the specific lender used by the applicant almost always reduces differences further, although unexplained differences remain between non-Hispanic whites and other racial and ethnic groups. For example, for home-purchase loans, the gross mean denial rate was 31.6 percent for blacks and 13.1 percent for non-Hispanic whites, a difference of 18.5 percentage points (table 13). Borrowerrelated factors reduce the difference to 14.6 percentage points, and lender adjustment further reduces it to 8.4 percentage points. The borrower-plus-lendermodified differences for refinance loans are similar to those for home purchase, although unmodified differences in denial rates tend to be smaller. The gross difference between denial rates for blacks and nonHispanic whites for refinancings is 14.3 percentage points, a difference cut about in half by borrowerplus-lender adjustment.
With regard to the sex of applicants, sole male applicants have nearly the same denial rate as sole females. For home-purchase loans, co-applicants, whether male or female, have somewhat lower denial rates than single individuals.

\section{Limitations of the Data on Differences across Groups}

The 2006 HMDA data, like those for 2004 and 2005, show that the incidence of higher-priced lending for blacks and Hispanic white borrowers is notably greater than for non-Hispanic whites and, for Asians, that the incidence is fairly close to that for nonHispanic whites. The borrower-plus-lender adjustment, discussed above, is insufficient to account fully for racial or ethnic differences in the incidence of higher-priced lending; significant differences remain unexplained. Similar patterns are shown in racial and ethnic differences in denial rates. By contrast, only small differences across groups were found in the mean spreads paid by those receiving higher-priced loans. Regarding the sex of borrowers, only small differences were found in lending outcomes.

In our analysis of the 2005 HMDA data regarding differences by race, ethnicity, and sex in the incidence of higher-priced lending and in the spreads paid by those with higher-priced loans, we presented differences both before and after adjusting the APRs to 
remove the effects of the flattening of the yield curve. Here, for 2006, we present only the differences before making the APR adjustment; they are similar to the differences remaining after that adjustment. But the changes in group differences between 2005 and 2006 are narrowed by the APR adjustment. For example, controlling for borrower-related factors plus lender, the gap in the incidence of higher-priced lending between black and non-Hispanic white homepurchase borrowers rose from 10.0 percentage points to 12.6 percentage points between 2005 and 2006; the comparable differences are 9.0 percentage points and 10.5 percentage points when adjusted APRs are used. Thus, the APR adjustment narrowed the 2005-06 rise in the gap from 2.6 percentage points to 1.5 percentage points. For refinancings, the unadjusted difference in the incidence of higher-priced lending between blacks and non-Hispanic whites rose from 6.2 to 7.3 percentage points, whereas the gap after the APR adjustment was 5.6 percentage points in both years. These results suggest that at least a portion of the apparent widening of gaps in the incidence of higher-priced lending across racial groups for homepurchase lending was due to the further flattening of the yield curve during 2006. For refinancings, the yield-curve effects may explain all of the changes.

The unexplained differences in the incidence of higher-priced lending and in denial rates stem, at least in part, from credit-related factors not available in the HMDA data, such as measures of credit history (including credit scores), LTV ratios, debt-to-income (DTI) ratios, and differences in choice of loan product. Differential costs of loan origination and the competitive environment also likely bear on the differences in pricing; so may differences in financial literacy, which can lead to differences in creditshopping activities and negotiating. Differences in pricing and underwriting outcomes may also reflect discriminatory treatment of minorities or other actions by lenders, including marketing practices. Further research is needed to assess the extent to which credit- or cost-related factors account for the unexplained differences in loan pricing and denial rates.

\section{CREDIT SCORES BY AREA AND HIGHER- PRICED LENDING}

For some time, the staff of the Federal Reserve Board has been using information on the credit experiences of consumers as reflected in their credit records and by their credit history scores to research related public policy issues. Some of that research has focused on the utility of credit scoring and its effects on credit availability and affordability for different populations. ${ }^{42}$ Other staff research has considered the relationship between the accuracy of credit reporting and access to credit. ${ }^{43}$ Most of this research has been undertaken using nationally representative samples of the credit records of individuals (with no personally identifiable information in the data). These data include the full range of information contained in the credit records of these individuals as assembled by TransUnion, one of the three national credit-reporting agencies. ${ }^{44}$

A second type of credit-record-related information has also been used in the Board staff's research: summary statistics about the credit scores of individuals aggregated at the census-tract level. ${ }^{45}$ These data, also provided by TransUnion, include, for each census tract, information on the mean credit scores and the distribution of credit scores for individuals with an outstanding mortgage and for other individuals for whom TransUnion could calculate a credit score. The statistics were constructed by TransUnion using their TransRisk Account Management Score (TransRisk Score). ${ }^{46}$ The data also include the percentage of individuals who have a credit record but could not be scored at the time the data were assembled, most often because their credit accounts were not sufficiently numerous or did not show enough recent activity to calculate a TransRisk Score. The thresholds selected for the different segments of the credit score distribution correspond roughly to the cutoffs that, based on credit scores alone, would place individuals in the prime, near-prime, and subprime price ranges. The census-tract credit-score data are constructed from the credit records of approximately

42. Board of Governors of the Federal Reserve System (2007), Report to the Congress on Credit Scoring and Its Effects on the Availability and Affordability of Credit (Washington: Board of Governors, August), www.federalreserve.gov/boarddocs/RptCongress/ creditscore/creditscore.pdf.

43. For a discussion of credit-reporting accuracy and access to credit and for references to research on this subject, refer to two 2004 articles by Robert B. Avery, Paul S. Calem, and Glenn B. Canner: "Credit Report Accuracy and Access to Credit," Federal Reserve Bulletin, vol. 90 (Summer), pp. 297-322; and "Consumer Credit Scoring: Do Situational Circumstances Matter," Journal of Banking and Finance, vol. 28 (April), pp. 835-56.

44. TransUnion LLC, www.transunion.com. The other two national credit-reporting agencies are Equifax, www.equifax.com; and Experian, www.experian.com

45. Refer to Avery, Brevoort, and Canner, "Higher-Priced Home Lending and the 2005 HMDA Data."

46. The TransRisk Scores were generated by TransUnion using their proprietary model for assessing the credit risk of existing credit accounts. TransRisk Account Management Score is a registered trademark of TransUnion LLC; other trademarks, service marks, and brands referred to in this article are the property of their respective owners. 
14. Distribution of individuals, by characteristic of census tract and by type of credit record, borrower status, and credit score range, 2005

Percent

\begin{tabular}{|c|c|c|c|c|c|c|c|c|}
\hline \multirow{4}{*}{$\begin{array}{l}\text { Census tract category } \\
\text { and subcategory }\end{array}$} & \multicolumn{8}{|c|}{ Scorable } \\
\hline & \multicolumn{8}{|c|}{ Mortgage borrowers } \\
\hline & \multicolumn{2}{|c|}{ Low } & \multicolumn{2}{|c|}{ Middle } & \multicolumn{2}{|c|}{ High } & \multirow[b]{2}{*}{ Total } & \multirow{2}{*}{$\begin{array}{c}\text { Мемо: } \\
\text { Percent of } \\
\text { census tract } \\
\text { population } \\
\text { with a credit } \\
\text { record }^{3}\end{array}$} \\
\hline & $\begin{array}{l}\text { Percent } \\
\text { of census } \\
\text { tract sub- } \\
\text { category }\end{array}$ & $\begin{array}{l}\text { Percent of } \\
\text { census tract } \\
\text { category }^{2}\end{array}$ & $\begin{array}{l}\text { Percent } \\
\text { of census } \\
\text { tract sub- } \\
\text { category }{ }^{1}\end{array}$ & $\begin{array}{l}\text { Percent of } \\
\text { census tract } \\
\text { category }^{2}\end{array}$ & $\begin{array}{l}\text { Percent } \\
\text { of census } \\
\text { tract sub- } \\
\text { category }\end{array}$ & $\begin{array}{l}\text { Percent of } \\
\text { census tract } \\
\text { category }^{2}\end{array}$ & & \\
\hline \multicolumn{9}{|l|}{$\begin{array}{c}\text { Income ratio (percent of } \\
\text { area median) }\end{array}$} \\
\hline Less than $50 \ldots \ldots$.... & 24.9 & 2.9 & 16.4 & 2.0 & 58.7 & 0.9 & 100 & 4.7 \\
\hline $50-79 \ldots \ldots \ldots$ & 18.1 & 21.1 & 14.4 & 17.3 & 67.5 & 10.0 & 100 & 10.7 \\
\hline $80-119 \ldots \ldots \ldots \ldots \ldots$ & 11.2 & 56.7 & 10.8 & 56.0 & 78.1 & 50.4 & 100 & 20.6 \\
\hline 120 or more $\ldots \ldots \ldots \ldots$ & 5.5 & 19.3 & 7.0 & 24.8 & 87.5 & 38.7 & 100 & 28.9 \\
\hline Total ............. & $\cdots$ & 100 & $\ldots$ & 100 & . & 100 & $\ldots$ & . \\
\hline \multicolumn{9}{|l|}{$\begin{array}{l}\text { Racial or ethnic composition } \\
\text { (minorities as a } \\
\text { percentage of } \\
\text { population) }\end{array}$} \\
\hline Less than $10 \ldots \ldots \ldots \ldots$ & 8.5 & 34.1 & 8.9 & 36.6 & 82.6 & 42.3 & 100 & 25.9 \\
\hline $10-49 \ldots \ldots$ & 9.4 & 42.2 & 9.6 & 44.0 & 81.0 & 46.2 & 100 & 20.3 \\
\hline $50-79 \ldots \ldots$ & 15.3 & 12.4 & 13.1 & 10.9 & 71.6 & 7.4 & 100 & 12.5 \\
\hline $80-100$ & 21.9 & 11.3 & 15.9 & 8.4 & 62.1 & 4.1 & 100 & 8.7 \\
\hline Total $\ldots \ldots \ldots$ & $\ldots$ & 100 & $\ldots$ & 100 & $\ldots$ & 100 & $\ldots$ & $\ldots$ \\
\hline $\begin{array}{l}\text { Mемо: } \\
\text { Census tract unknown }\end{array}$ & 11.1 & $\ldots$ & 10.7 & $\ldots$ & 78.2 & $\ldots$ & 100 & 10.2 \\
\hline Total ....... & 10.2 & $\ldots$ & 9.9 & $\ldots$ & 79.9 & $\ldots$ & 100 & 19.2 \\
\hline
\end{tabular}

Note. The credit score ranges are based on the TransRisk Account Management Score (TransRisk Score) as of December 31, 2005. TransRisk Account Management Score is a registered trademark of TransUnion LLC.

1. Distribution sums horizontally. For example, the first column, first row shows that 24.9 percent of scorable mortgage borrowers in census tracts with an income ratio of less than 50 percent had credit scores in the low range.

27 million anonymous individuals drawn from stratified, nationally representative random samples of all the credit records maintained by TransUnion. ${ }^{47}$

With the geographic identifiers included in each data file, the census-tract credit score can be combined with the HMDA data and with information from the 2000 decennial census. For the analysis here, credit scores by census tract (not scores of individuals separately) were obtained for two specific dates: December 31, 2004, and December 31, 2005.48 Given the large proportion of all outstanding mortgages originated in just the past few years, the census-tract credit-score data for mortgage holders

47. Information on census tract was not available for all individuals.

48. The census-tract credit scores do not provide information about the specific credit score that may have been used to assess the credit risk of any individual mortgage borrower included in the HMDA data; that information is proprietary to the lender and is not reported under HMDA. Also, the samples of credit records drawn in 2004 and 2005 were chosen randomly and do not necessarily include the same individuals.
2. Distribution sums vertically. For example, the second column, first row shows that 2.9 percent of scorable mortgage borrowers with credit scores in the low range lived in a census tract with an income ratio of less than 50 percent.

3. Memo items sum horizontally.

4. The income ratio of a census tract is the median family income of the tract relative to that of the area (MSA or statewide non-MSA) in which the tract is located.

... Not applicable.

are likely quite representative of the individuals who received a mortgage over this period. ${ }^{49}$

\section{National Distribution of Credit Scores}

The analysis here uses the 2005 file of credit scores by census tract because its information is the nearest in time to the 2006 HMDA data and because it is likely a reasonable approximation of the credit scores of individuals taking out mortgages during 2006. Nationally, about 15 percent of individuals with a credit record were unscorable; about 19 percent of individuals had a mortgage, and 66 percent did not (table 14, memo items). ${ }^{50}$ The distribution of credit

49. As of December 2006, according to data from First American LoanPerformance, about 80 percent of outstanding first-lien mortgages had been originated in 2003 or later (www.loanperformance .com).

50. One difficulty reconciling these shares with other data sources is that credit records are for individuals, whereas the household or family is the unit of analysis typically used in statistics on homeownership and mortgage holding. Virtually everyone in the database who 
14. Distribution of individuals, by characteristic of census tract and by type of credit record, borrower status, and credit score range, 2005-Continued

Percent

\begin{tabular}{|c|c|c|c|c|c|c|c|c|c|c|}
\hline \multirow{2}{*}{\multicolumn{8}{|c|}{$\begin{array}{c}\text { Scorable } \\
\text { Others }\end{array}$}} & \multicolumn{2}{|c|}{ Unscorable } & \multirow{4}{*}{$\begin{array}{c}\text { Incidence } \\
\text { of higher } \\
\text { priced } \\
\text { lending }\end{array}$} \\
\hline & & & & & & & & \multirow{3}{*}{$\begin{array}{l}\text { Mемо: } \\
\text { Percent of } \\
\text { census tract } \\
\text { population } \\
\text { with a credit } \\
\text { record }^{3}\end{array}$} & \multirow{3}{*}{$\begin{array}{l}\text { Percent of } \\
\text { census tract } \\
\text { category }^{2}\end{array}$} & \\
\hline \multicolumn{2}{|c|}{ Low } & \multicolumn{2}{|c|}{ Middle } & \multicolumn{2}{|c|}{ High } & \multirow[b]{2}{*}{ Total } & \multirow{2}{*}{$\begin{array}{c}\text { Мемо: } \\
\text { Percent of } \\
\text { census tract } \\
\text { population } \\
\text { with a credit } \\
\text { record }^{3} \\
\end{array}$} & & & \\
\hline $\begin{array}{l}\text { Percent } \\
\text { of census } \\
\text { tract sub- } \\
\text { category }{ }^{1}\end{array}$ & $\begin{array}{l}\text { Percent of } \\
\text { census tract } \\
\text { category }{ }^{2}\end{array}$ & $\begin{array}{l}\text { Percent } \\
\text { of census } \\
\text { tract sub- } \\
\text { category }{ }^{1}\end{array}$ & $\begin{array}{l}\text { Percent of } \\
\text { census tract } \\
\text { category }^{2}\end{array}$ & $\begin{array}{l}\text { Percent } \\
\text { of census } \\
\text { tract sub- } \\
\text { category }\end{array}$ & $\begin{array}{l}\text { Percent of } \\
\text { census tract } \\
\text { category }\end{array}$ & & & & & \\
\hline 49.8 & 6.9 & 14.8 & 4.7 & 35.4 & 2.2 & 100 & 67.1 & 28.1 & 9.6 & 46.5 \\
\hline 38.8 & 28.3 & 14.3 & 23.9 & 46.8 & 15.4 & 100 & 68.1 & 21.2 & 31.5 & 38.8 \\
\hline 26.4 & 49.7 & 12.0 & 51.8 & 61.6 & 52.3 & 100 & 66.4 & 13.0 & 43.8 & 27.7 \\
\hline 16.6 & 15.1 & 9.5 & 19.6 & 73.9 & 30.2 & 100 & 61.9 & 9.2 & 15.1 & 18.3 \\
\hline$\ldots$ & 100 & $\ldots$ & 100 & $\ldots$ & 100 & $\ldots$ & $\ldots$ & $\ldots$ & 100 & $\ldots$ \\
\hline 19.9 & 24.1 & 10.1 & 28.1 & 70.0 & 28.1 & 100 & 64.4 & 9.7 & 20.7 & 21.7 \\
\hline 26.2 & 43.0 & 11.9 & 44.6 & 61.9 & 44.6 & 100 & 65.8 & 13.9 & 42.2 & 24.8 \\
\hline 37.1 & 16.1 & 14.2 & 14.1 & 48.7 & 14.1 & 100 & 67.1 & 20.4 & 18.2 & 36.3 \\
\hline 45.2 & 16.8 & 15.6 & 13.2 & 39.2 & 13.2 & 100 & 67.7 & 23.6 & 19.0 & 46.6 \\
\hline$\ldots$ & 100 & $\ldots$ & 100 & $\ldots$ & 100 & $\ldots$ & $\ldots$ & $\ldots$ & 100 & $\ldots$ \\
\hline 32.7 & $\ldots$ & 13.0 & $\ldots$ & 54.3 & $\ldots$ & 100 & 66.7 & 23.2 & $\ldots$ & 26.9 \\
\hline 27.5 & $\ldots$ & 12.0 & $\ldots$ & 60.5 & $\ldots$ & 100 & 65.8 & 15.0 & $\ldots$ & 27.0 \\
\hline
\end{tabular}

scores differs for mortgage borrowers and others: Overall, about 80 percent of individuals with a mortgage, but only about 61 percent of other individuals with a credit score, had relatively high credit scores, that is, scores that (everything else being equal) would make them eligible for the most attractive interest rates available for home loans. At the other end of the spectrum, about 10 percent of mortgage borrowers and 28 percent of other individuals who could be scored had relatively low credit scores, that is, scores that (everything else being equal) would be consistent with placement in the subprime-loan market.

\section{Distribution of Credit Scores across Census Tracts}

The broad differences in the distribution of credit scores for mortgage borrowers and other individuals, noted above, hold across census tracts grouped along a variety of socioeconomic dimensions. ${ }^{51}$ However,

had a record of an outstanding mortgage had a credit score. However, although some individuals with credit scores were likely unscorable at the time they received their mortgage loan, they became scorable as their credit records "thickened" with the reports of their periodic payments on the debt. The proportion of individuals that are unscorable depends on the credit-scoring model. Model builders differ on the criteria used to determine scorability.

51. Census tracts differ along a range of socioeconomic metrics. In part, these differences are by design, as one of the objectives in defining census-tract boundaries is to group smaller geographic areas the distributions of scores differ across census tracts grouped by relative income and racial or ethnic composition. Individuals in higher-income census tracts (in which the median family income is 120 percent or more of the median for the broader area) tend to have higher credit scores than individuals in other areas. These patterns hold both for the population of individuals with a mortgage and for others. For example, on average, 88 percent of scorable individuals with a mortgage who resided in higher-income census tracts had relatively high credit scores, as did 74 percent of other individuals. By comparison, 59 percent of the mortgage borrowers who could be scored and who resided in low-income census tracts had relatively high credit scores, as did 35 percent of other scorable individuals in low-income census tracts. Also, the proportion of individuals in higherincome census tracts who were unscorable was notably smaller than that of individuals in low-income areas-9 percent and 28 percent respectively.

The distribution of credit scores also differs across census tracts sorted by the proportion of census-tract population that is minority. In predominantly nonminority census tracts (less than 10 percent minority

that have similar population and economic circumstances. According to the Census Bureau, census tracts usually have a population of between 2,500 and 8,000 and, when first delineated, are designed to be homogeneous with respect to population characteristics, economic status, and living conditions (www.census.gov). 
population), about 83 percent of the mortgage borrowers and 70 percent of others with a credit score had relatively high credit scores. In census tracts with a minority population exceeding 80 percent, 62 percent of the mortgage borrowers and 39 percent of others with a credit score had relatively high credit scores. Once again, the percentage of individuals without a credit score differs greatly across censustract groupings. In predominantly nonminority areas, 10 percent of the individuals could not be assigned a credit score; in contrast, 24 percent of the individuals in census tracts with more than 80 percent minority individuals were unscorable.

Note that in considering differences in credit scores across census tracts grouped by racial or ethnic makeup, differences in score arise solely from differences in the content of credit records; so, for example, two individuals with identical credit records will receive identical credit scores regardless of any difference between them in racial or ethnic identity. No information on location, race or ethnicity, sex, or other personal demographic characteristic is used in calculating generic credit history scores, such as the TransRisk Score. ${ }^{52}$

\section{Distribution of Credit Scores across Counties}

The data on credit scores by census tract can be aggregated to broader geographic areas, including counties, metropolitan statistical areas (MSAs), and states. The South and Southwestern sections of the country and portions of the Midwest stand out because they have relatively low mean credit scores (figure 3). By contrast, mean scores for mortgage borrowers in the Northeast, in the upper Great Plains, and on the West Coast have relatively high mean scores.

\section{Credit Scores and the Incidence of Higher- Priced Lending}

Individuals with lower credit scores are more likely to receive higher-priced loans. ${ }^{53}$ Likewise, the HMDA data show that census tracts with larger shares of individuals who have relatively low credit scores and a mortgage also have larger shares of individuals who received higher-priced loans (table 15). For example, in census tracts in which more than 20 percent of the mortgage borrowers had low credit scores as of the

52. Board of Governors of the Federal Reserve System, Report to the Congress on Credit Scoring and Its Effects on the Availability and Affordability of Credit.

53. For example, refer to Board of Governors of the Federal Reserve System, Report to the Congress on Credit Scoring and Its Effects on the Availability and Affordability of Credit. end of 2005, 45 percent of the homebuyers in 2006 using conventional first liens to purchase site-built homes or to refinance such liens had higher-priced loans; in census tracts in which the share of mortgage borrowers with low credit scores was less than 3 percent, the incidence of higher-priced lending was only 14 percent.

Both the relative income of a census tract and the minority percentage are associated with the incidence of higher-priced lending (table 14). Further analysis (not shown in tables) indicates that the incidence of higher-priced lending across census tracts (after accounting for the income and racial or ethnic composition of the census tract) can be further explained by census-tract data on mean credit scores and on the proportion of individuals with credit scores in the categories roughly corresponding to the near-prime and subprime markets. For example, consider census tracts arrayed into quintiles ranked by relative income and, within each quintile, further subdivided by mean credit score: The census tracts with lower mean credit scores have a higher incidence of higher-priced lending in the 2006 data (by about 4 percentage points) than census tracts with the same income level but higher mean credit scores. A similar relationship is found when census tracts are grouped by minority percentage or when the analysis is restricted to nonHispanic whites.

\section{LOAN PERFORMANCE AND THE HMDA DATA}

As of this writing, conditions in the mortgage market are the subject of considerable concern. Delinquency and foreclosure rates have risen substantially, particularly in the higher-priced segment of the market, and lax underwriting is widely believed to have contributed to the rise in defaults. Also, a significant share of the higher-priced loans apparently involve adjustable rates; such loans carry the potential to significantly increase monthly payments and, hence, to place greater burdens on many mortgage borrowers.

Although the HMDA data are limited, they can be combined with other data to better understand the linkages between loan pricing, economic factors, and mortgage loan performance. We pursue such an analysis here, focusing on variations in rates of serious delinquency (payment overdue for ninety days or more) on mortgages across MSA counties. Specifically, we examine the relationship between the rates of serious delinquency on mortgages as of March 31, 2007, and (1) the incidence of higherpriced lending (from the HMDA data) for 2005 and 2006 and (2) county-level economic indicators measured over the 2002-06 period. 


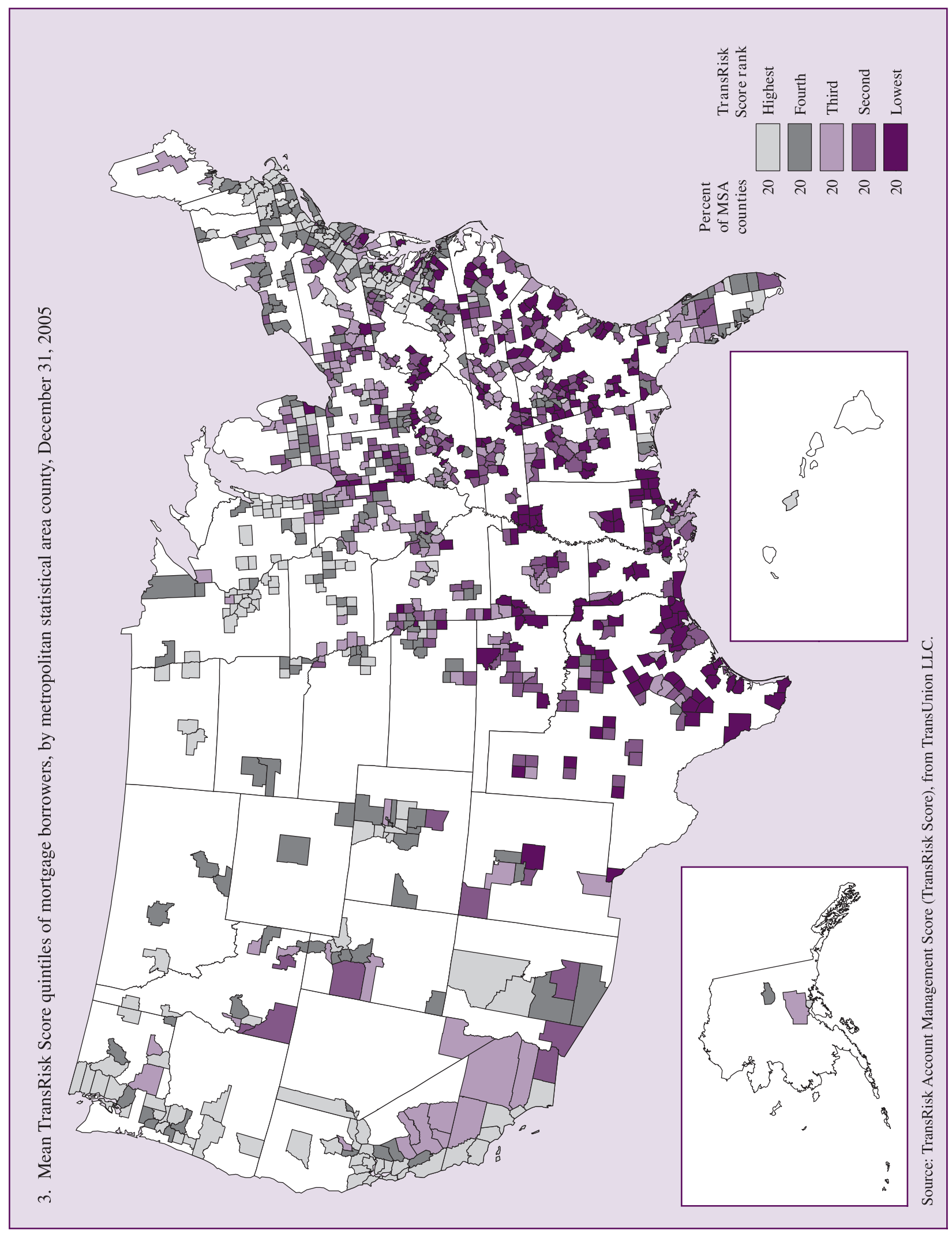


15. Credit scores and the incidence of higher-priced lending, 2006

Percent

\begin{tabular}{|c|c|}
\hline $\begin{array}{c}\text { Share of mortgage borrowers } \\
\text { in census tract who have low } \\
\text { credit scores }\end{array}$ & $\begin{array}{c}\text { Share of mortgage loans } \\
\text { in census tract that are } \\
\text { higher priced }\end{array}$ \\
\hline $0-2.9$ & 13.9 \\
\hline $3-6.9$ & 19.8 \\
\hline $7-9.9 \ldots$ & 25.3 \\
\hline $10-14.9$ & 27.4 \\
\hline $15-19.9 \ldots$ & 34.7 \\
\hline 20 or more & 45.4 \\
\hline All tracts.. & 27.0 \\
\hline
\end{tabular}

Note: Lending covers first-lien purchase or refinancing loans for site-built homes. Refer also to general note to table 14 .

The analysis employs a proprietary database, TrenData, that measures loan performance at a reasonably disaggregated geographic level. ${ }^{54}$ TrenData is based on the credit records of individuals, which makes it one of the most comprehensive databases on the performance of mortgages. In particular, the information has been drawn from the credit records of a geographically stratified random sample of about 30 million individuals for each calendar quarter since 1992. The data (available by county, MSA, and state and for the nation as a whole) include more than 200 measures of credit use and loan performance, including the proportion of mortgage borrowers in a county who are at least ninety days delinquent on their mortgages. ${ }^{55}$

Using TrenData, we created a map of the fifty states showing mortgage delinquency rates by MSA county (figure 4). MSA counties are grouped into quintiles ranked by their rate of serious mortgage delinquency as of March 31, 2007. The counties vary considerably in the level of problem loans, but most areas had rates of serious delinquency that are relatively low. About 35 percent of the MSA counties had a serious delinquency rate below 1 percent, and only 5 percent had a serious delinquency rate greater than 3 percent. Areas of the country with the highest levels of serious delinquency were in western Pennsylvania, Ohio, Indiana, and Michigan; in the southeastern states and along the rest of the Gulf Coast area; and in Texas, Oklahoma, and Colorado.

We also mapped the 2006 HMDA data on the incidence of higher-priced lending by MSA county (figure 5). A comparison of figure 4 with figure 5 is

54. TrenData is a registered trademark of TransUnion LLC (products.trendatatu.com/faqs.asp).

55. All lenders selling their loans to Fannie Mae or Freddie Mac must report loan performance to the three national credit-reporting agencies. Virtually all banking institutions also report loan performance on the loans they service or hold in portfolio. Other loans, such as those from smaller lenders or seller financings, are less likely to be reported. revealing. For the most part, MSA counties with elevated rates of higher-priced lending also had elevated rates of serious mortgage delinquency. Notable exceptions in one direction are some MSA counties in Florida, California, New York, Pennsylvania, and New Jersey that were in the top quintile of the incidence of higher-priced lending but that had relatively moderate levels of serious delinquency. ${ }^{56}$ Notable exceptions in the other direction are many of the MSA counties in Michigan, Indiana, Ohio, Colorado, western Pennsylvania, and the southeastern states, which had high levels of mortgage delinquency but were not in the highest quintile of the incidence of higher-priced lending. ${ }^{57}$

In general, we expect both loan pricing and delinquency to be driven by economic factors. Unfortunately, few high-frequency measures of economic conditions are available at the county level. Available items include the unemployment rate, per capita income, house-price appreciation, and population growth; credit scores and other information drawn from credit records are also available. Each of these factors may influence loan performance and the incidence of higher-priced lending, but no single factor stands out. Consequently, for our analysis, we construct a composite of economic factors (by regressing the TrenData delinquency measure of loan performance against several county-level indicators) as a representative measure of economic circumstances. ${ }^{58}$

The coefficient weights from this regression are used to form the composite economic variable used here. That variable can also be viewed as a predictorbased only on the economic factors described above- of the rate of serious mortgage delinquency

56. Although these areas have average or lower levels of serious delinquency, they are all in the top quintile when measured by the increase in rates of serious delinquency from the last quarter of 2004 through the first quarter of 2007.

57. The delinquency rates presented here are as of only a single date-March 31, 2007; some areas of the country that have had relatively low rates of serious delinquency have been experiencing sharp increases in those rates more recently.

58. The composite measure is constructed by regressing the TrenData delinquency measure of loan performance against the following county-level economic factors: the unemployment rates in 2005 and 2006 and the change in the unemployment rate from 2002 to 2005; the rates of house price appreciation from 2001 to 2004 and from 2004 to 2006; the level of per capita income in 2005 and the change in per capita income from 2002 to 2005; the population growth rate from 2002 to 2005; and, as of the end of 2004, the mean credit score of mortgage holders and the percentage of mortgage holders in the two lowest score groupings as described earlier. We also include the average share of HMDA loans secured by non-owner-occupied houses in each county in 2005 and 2006 as a measure of the importance of investor activity. Data on house-price appreciation are from the Office of Federal Housing Enterprise Oversight (www.ofheo.gov); unemployment rates, from the Bureau of Labor Statistics (www.bls.gov); and per capita income and population growth, from the Bureau of Economic Analysis (www.bea.gov). 


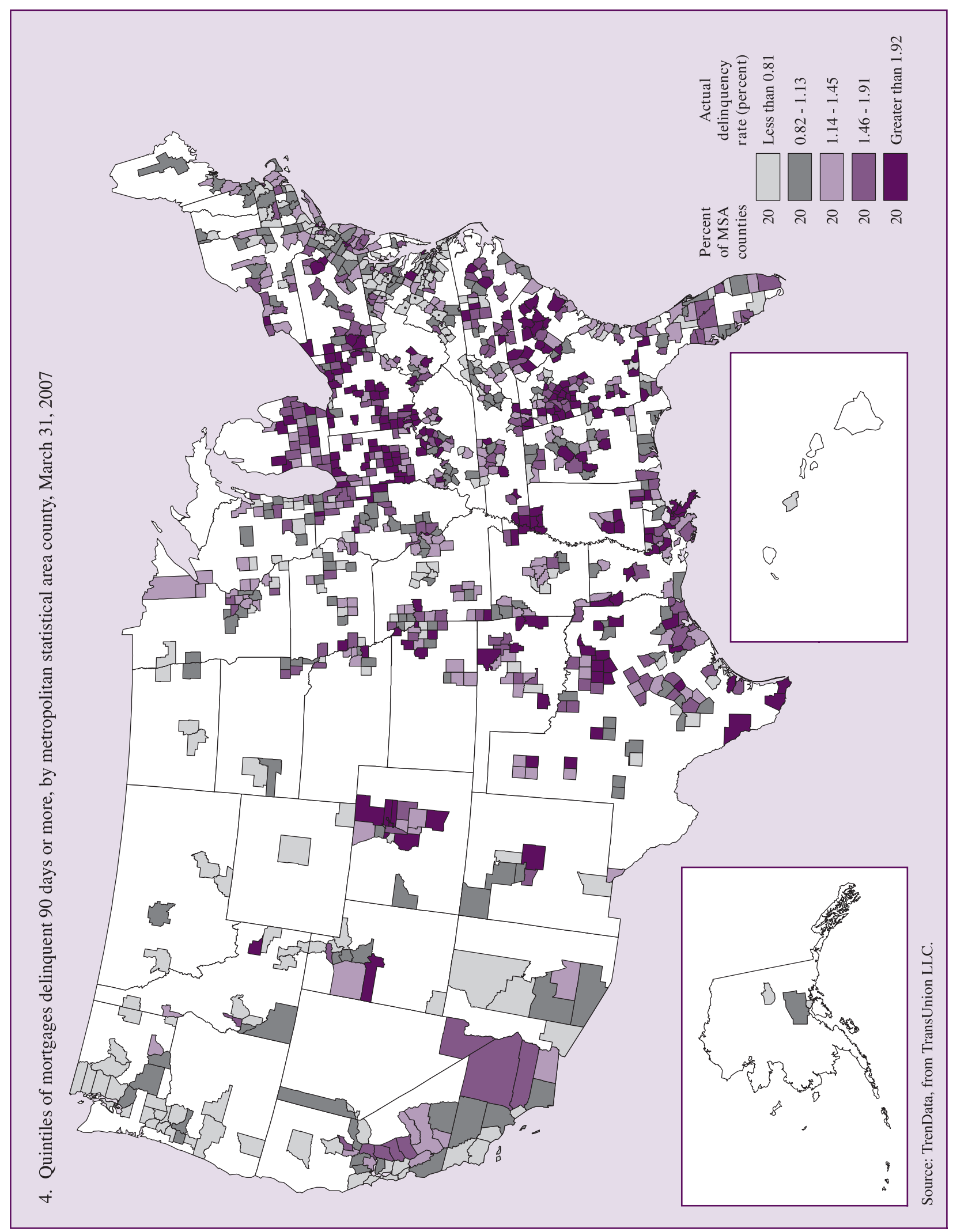




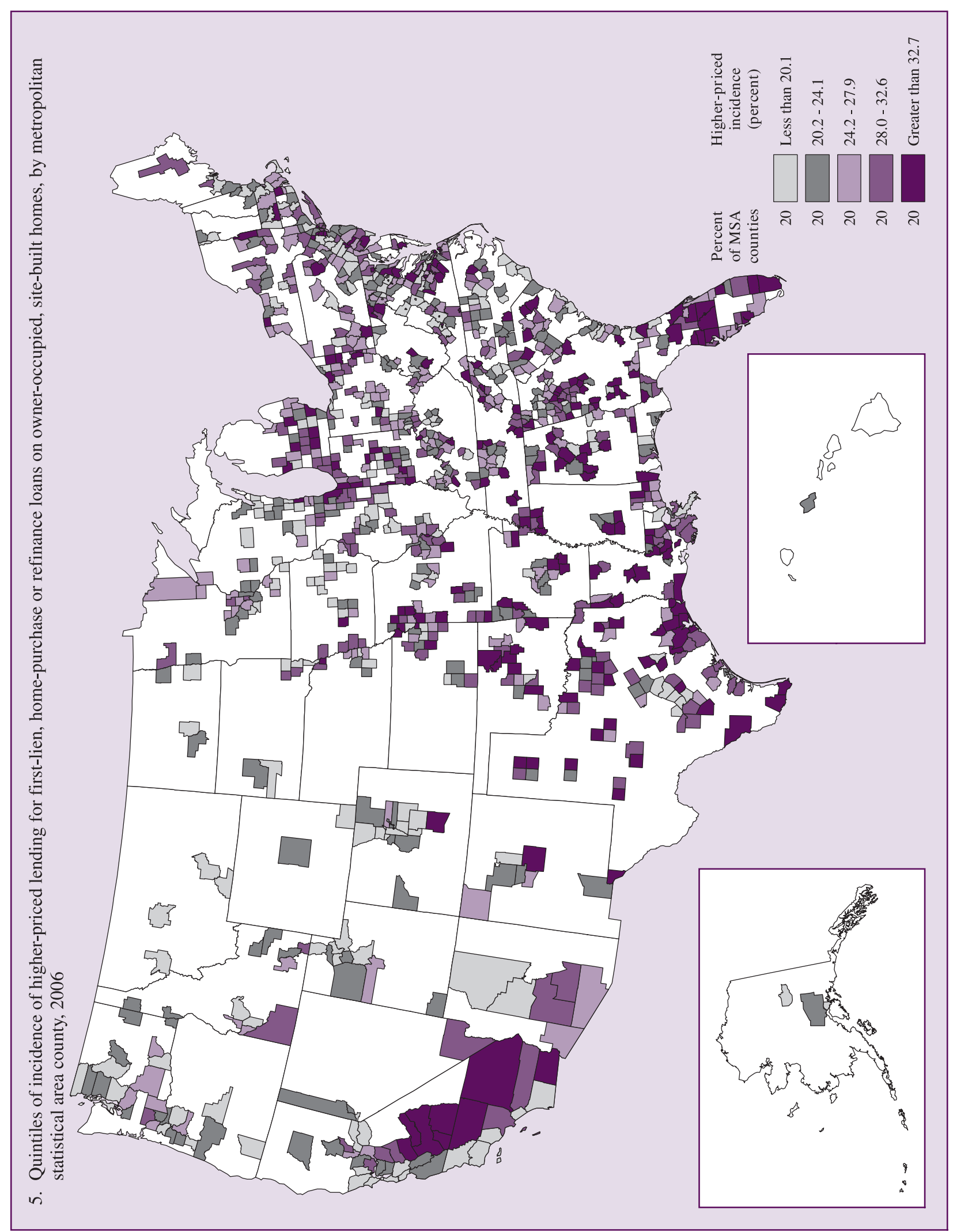


for the first quarter of 2007. As expected, each of the factors included in the regression played a role in predicting future mortgage loan performance. The most important factor, however, was house-price appreciation, particularly from 2004 to $2006 .{ }^{59}$

Figure 6 shows counties grouped by our composite economic variable. The MSA counties are grouped by their expected level of delinquency, applying the same cutoffs used for the actual delinquency rates in figure 4. Not surprisingly, the patterns in figures 4 and 6 show a high degree of correlation. Notable divergences appear in Colorado, where most MSA counties had higher levels of actual serious mortgage delinquency (figure 4) than would be expected on the basis of economic factors as measured here (figure 6); and in Florida, where the MSA counties generally had expected rates of delinquency higher than the actual rates.

\section{FURTHER ANALYSIS RELATING HIGHER- PRICED LENDING TO LOAN PERFORMANCE}

The analysis in the previous section does not explicitly link the HMDA data on the incidence of higherpriced lending to mortgage loan performance. The figures show similar patterns for the incidence of higher-priced lending; the comparison of the results from the economic composite variable and the mortgage delinquency rates are suggestive, but it does not identify whether loan pricing data have additional power in predicting delinquency once economic factors are taken into account. To focus on this issue, we estimated a regression similar to that used to create the economic composite described above. But we added to the regression a variable reflecting the average incidence of higher-priced lending for mortgage loans reported in the 2005 and 2006 HMDA data for each MSA county. Other variables were added to reflect, for each state, the percentage of subprime and prime loans that had adjustable interest rates (as derived from First American LoanPerformance data on mortgages).

Results suggest that the incidence of higher-priced lending has independent predictive value for loan performance beyond that of the economic factors. All else being equal, an increase in the incidence of higher-priced lending of 1 percentage point implies an increase in the March 2007 rate of serious mortgage delinquency of 0.03 percentage point in an MSA county. Although the effect may seem small, it is, in fact, fairly large given the relatively low level of mortgage delinquency. For example, consider an MSA county with the median level of serious delin-

59. The R-squared value for the regression was 0.40 . quency (1.27 percent): Holding economic factors constant, an increase in the incidence of higher-priced lending of 10 percentage points in that county would raise its rate of serious mortgage delinquency 0.3 percentage point, to 1.57 percent-enough to move that county into the next highest quintile of counties ordered by serious loan delinquency (refer to rates of actual serious delinquency by quintiles of counties, shown in figure 4).

The relationship between the incidence of higherpriced lending and the rate of serious delinquency just described (a 1 percentage point increase in the incidence of higher-priced lending implies an increase of 0.03 percentage point in the delinquency rate) is robust and of a similar magnitude when the prediction changes from the level of serious delinquency as of March 2007 to the change in delinquency rates between 2004 and 2007. Finally, some evidence indicates that higher numbers of adjustable-rate mortgages are associated with higher rates of future serious loan delinquency, but the effect is small and is found only for prime mortgages. However, the data available here cannot identify which types of mortgages within an area are delinquent. Adjustable-rate mortgages may be more prone to delinquency, but their delinquency status is not reflected in the aggregated data used in this study. Also, some evidence indicates that delinquencies in adjustable-rate mortgages are a growing problem that may not be fully reflected in the delinquency rates for March 2007.

The statistical relationship between the incidence of higher-priced lending and future loan performance could be caused by several factors. The relationship may be direct: Perhaps the higher monthly payments associated with higher-priced lending are a greater burden on borrowers and lead to greater delinquency. However, the statistical associations we measure may also reflect the effects of other economic factors, which we were not able to include in our model and that are related both to higher rates of delinquency and to higher-priced lending. ${ }^{60}$ Such factors may include expected changes in home prices, foreclosure laws, the specific types of loans used to buy homes or refinance, and other factors used in underwriting and pricing loans.

Our analysis is largely suggestive and is relatively parsimonious. However, it does suggest that the pricing data in HMDA may be a useful source of information in understanding and predicting loan performance.

60. Additional analysis shows that the economic factors and the incidence of higher-priced lending are highly correlated. A regression relating the incidence of higher-priced lending in 2005 and 2006 with the economic factors included in the economic composite variables had an R-squared value of about 0.67 . 


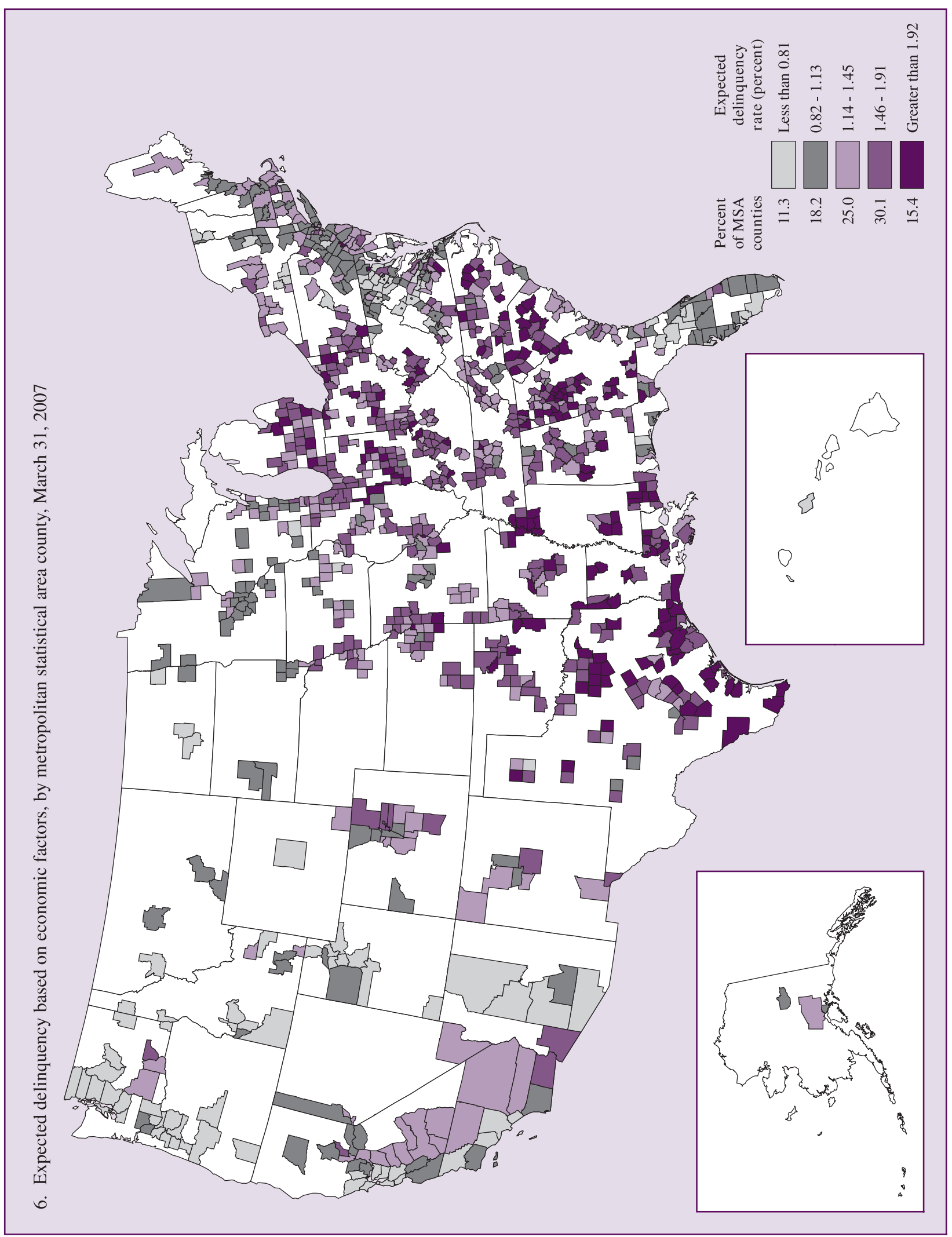




\section{APPENDIX: REQUIREMENTS OF REGULATION C}

Under the Home Mortgage Disclosure Act (HMDA), lenders use a "loan/application register" (HMDA/ LAR) to report information annually to their federal supervisory agencies for each application and loan acted on during the calendar year. Lenders must make their HMDA/LARs available to the public by March 31 following the year to which the data relate, and they must remove the two date-related fields (date of the loan application and date of the credit decision) to help preserve applicants' privacy. Lenders must make their date-modified register available to the public for a period of three years.

Only lenders that have offices (or, for nondepository institutions, are deemed to have offices) in metropolitan areas are required to report under HMDA. However, if a lender is required to report, it must report information on all of its home loan applications and loans in all locations, including nonmetropolitan areas.

The Federal Reserve Board's Regulation C requires lenders to report the following information on homepurchase and home-improvement loans and on the refinancing of such loans:

For each application or loan

- application date and the date an action was taken on the application

- action taken on the application

— approved and originated

- approved but not accepted by the applicant

- denied (with the reasons for denial-voluntary for some lenders)

- withdrawn by the applicant

- file closed for incompleteness

- pre-approval program used (for home-purchase loans only)

- amount
- type

- conventional

— insured by the Federal Housing Administration

- guaranteed by the Veterans Administration

- backed by the Farm Service Agency or Rural Housing Service

- pre-approval status

- status

- first lien

- junior lien

- unsecured

- purpose

- home purchase

- refinance

- home improvement

- of purchaser (if the lender subsequently sold the loan)

For each applicant or co-applicant

- ethnicity

- income relied on in credit decision

For each property

- location, by state, county, and census tract

- of structure

- one-to four-family dwelling

- manufactured home

— multifamily property (dwelling with five or more units)

- occupancy status (owner occupied or non-owner occupied)

For loans subject to price reporting

- spread above comparable Treasury security

For loans subject to HOEPA

- indicator of whether loan is subject to HOEPA

Institutions also report information on home loans they purchased during the calendar year. 